Florida International University FIU Digital Commons

3-7-1994

\title{
Comparison of parental perception and therapist interpretation of child's performance of the Peabody Fine Motor Scale
}

Martha Gene Belote

Florida International University

DOI: $10.25148 /$ etd.FI14050488

Follow this and additional works at: https://digitalcommons.fiu.edu/etd

Part of the Occupational Therapy Commons

\section{Recommended Citation}

Belote, Martha Gene, "Comparison of parental perception and therapist interpretation of child's performance of the Peabody Fine Motor Scale" (1994). FIU Electronic Theses and Dissertations. 1489.

https://digitalcommons.fiu.edu/etd/1489 
FLORIDA INTERNATIONAL UNIVERSITY

$$
\text { Miami, Florida }
$$

\author{
COMPARISON OF PARENTAL PERCEPTION \\ AND THERAPIST INTERPRETATION OF CHILD'S \\ PERFORMANCE OF THE PEABODY FINE MOTOR SCALE
}

A thesis submitted in partial satisfaction of the requirements for the degree of MASTER OF SCIENCE

IN

OCCUPATIONAL THERAPY

by

Martha Gene Belote 
To: $\frac{\text { Dean William J. Keppler }}{\text { College of Health }}$

This thesis, written by Martha Gene Belote, and entitled Comparison of Parental Perception and Therapist

Interpretation of Child's Performance of the Peabody Fine Motor Scale, having been approved in respect to style and intellectual content, is referred to you for judgement.

We have read this thesis and recommend that it be approved.

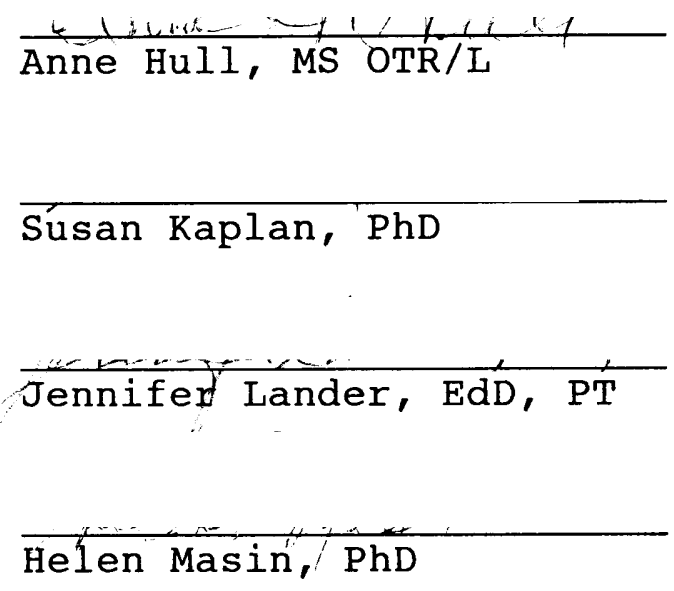

Date of Defense: March 7, 1994

The thesis of Martha Gene Belote is approved.

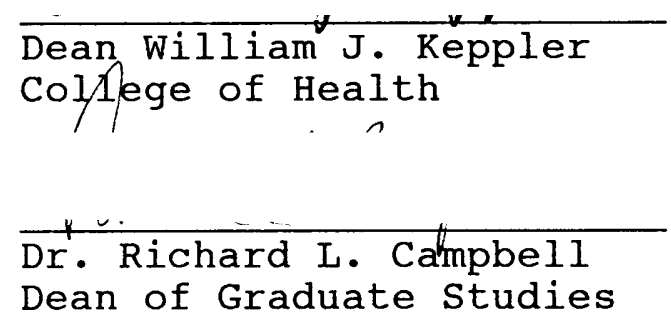

Florida International University, 1994 
I dedicate this thesis to my parents. Without their patience and support, and most of all love, the completion of this work would not have been possible. 


\section{ACKNOWLEDGEMENTS}

I wish to thank all the members of my committee for their helpful comments and support and especially Helen Masin for her "nugging". I would also like to thank Michelle Glick for her patience and assistance with my statistical analysis; Consuelo Rodriquez, Silvia Willumsen, Joyce Gonzalez and Yolanda Alvarez for their translations; and the therapy department at the Debbie School for their assistance, support, and understanding.

A special thanks goes to my major professor, Anne Hull. Without her guidance, understanding, and encouragement, I would never have completed this project. 


\author{
ABSTRACT OF THE THESIS \\ COMPARISON OF PARENTAL PERCEPTION AND THERAPIST \\ INTERPRETATION OF CHILD'S PERFORMANCE OF THE \\ THE PEABODY FINE MOTOR SCALE \\ by \\ Martha Gene Belote \\ Florida International University, 1994 \\ Miami, Florida \\ Professor Anne Hull, Major Professor
}

Public Law 102-119 (Individuals with Disabilities Education Act of 1991), mandates that family members, if they wish, participate in developing a plan of treatment for their child. Traditionally, therapist have not relied on parental assessments based upon the assumption that parents overestimate their child's abilities. The present study compared parental perceptions about the developmental status of their child's fine motor abilities to the therapist's interpretation of a standardized assessment using the Peabody Developmental Motor Scale (Fine Motor). Thirty seven children, enrolled in an early intervention program, and their parents were recruited for the study. The results indicated that the parents and the therapist estimates were highly correlated and showed no significant differences when paired $\underline{t}$-tests were computed for developmental ages and scaled scores. However, analyses of variances were significantly correlated for gender and number of siblings. 


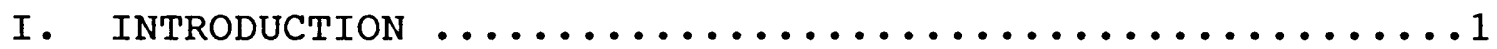

II. LITERATURE REVIEW ....................

Early Intervention and the Law $\ldots \ldots \ldots \ldots \ldots \ldots \ldots$

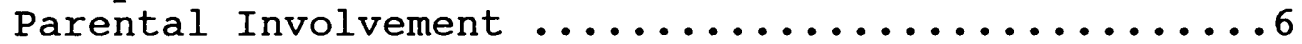

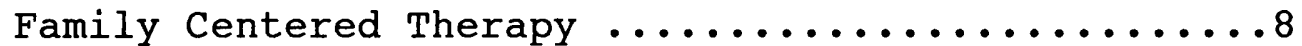

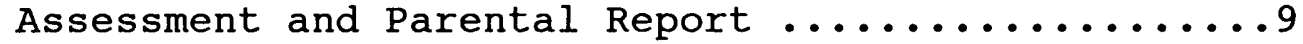

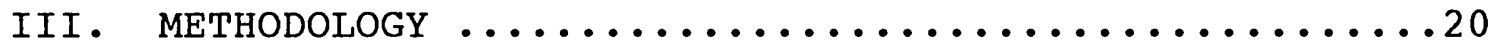

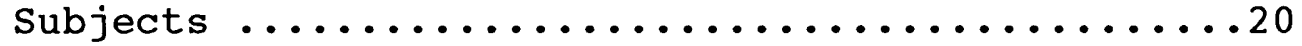

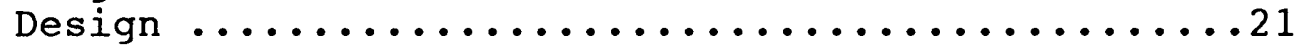

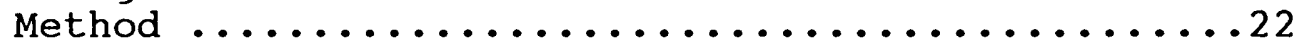

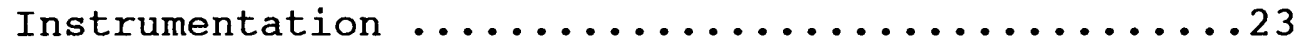

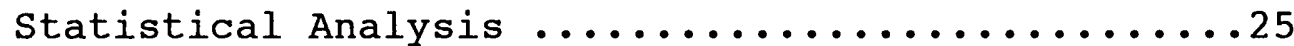

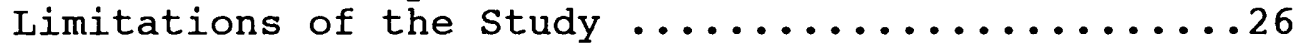

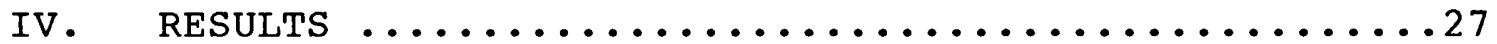

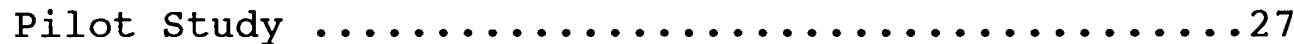

Pilot Compared to Current Study .............29

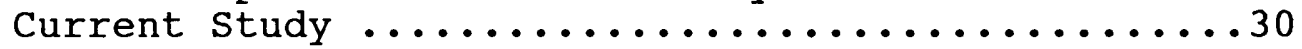

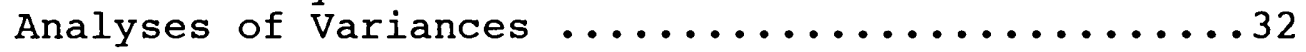

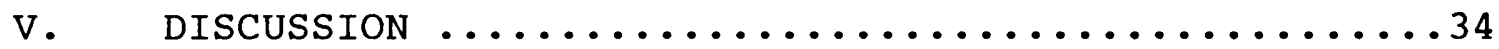

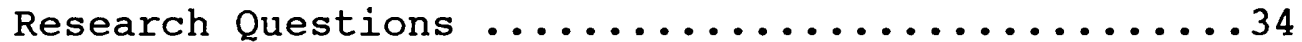

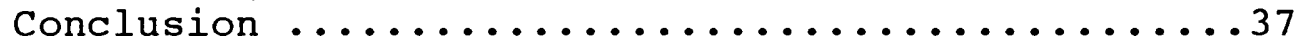

Recommendations for Future Research .........40

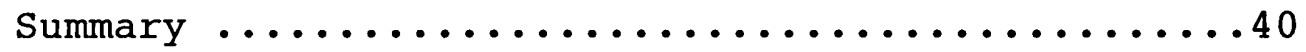

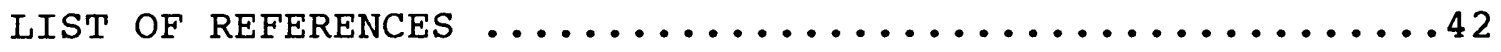

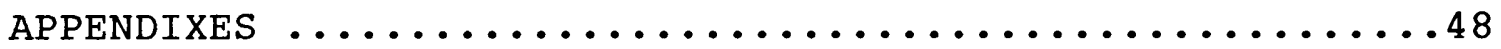




\section{LIST OF TABLES}

TABLE

PAGE

1. Differences Between Therapist Assessment and Mother's Perceptions of Child's Fine Motor

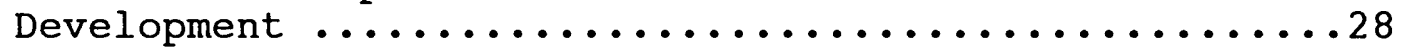

2. Comparison of Pilot study and Current study in

Relation to Developmental Age Scores and Scaled

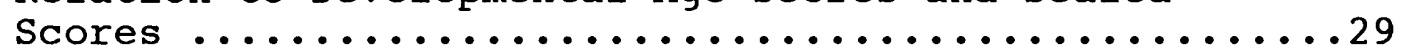

3. Differences Between Therapist Assessment and

Parental Perception of the Child's Fine Motor

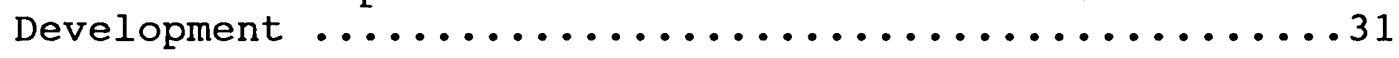

4. Comparison of Demographic Variables .............33 


\section{Chapter I}

\section{Introduction}

Early intervention provides services to children ages birth to three years. Attitudes and beliefs have changed considerably over the years regarding parent participation in their child's education and therapy. Bazyk (1989) describes this evolution in the following way: (1), the medical model, which involved limited parent participation; (2), the Education for All Handicapped Children Act (Public Law 94-142), which viewed parents as teachers and therapists; and (3), the Education of the Handicapped Act Amendments of 1986 (Public Law 99-457), which involves family-centered parent participation. More currently, the Individuals with Disabilities Education Act of 1991 (Public Law 102-119) was established by combining Public Law 94-142 and Public Law 99-457, strengthening the family involvement in all aspects of their child's welfare and development. Public Law 99-457, the Education of the Handicapped Act Amendments of 1986, mandates that assessment, service planning, and intervention must be done "with full participation and agreement of the parents of the child" (Nash, 1990, p. 318). Occupational therapists, as an important part of the multidisciplinary team, have been mandated to shift towards increased parental involvement. Professionals have been trained to be the expert and hence make what they feel the best decisions for families of 
handicapped children. Professionals could remove barriers to family involvement by "reframing the notion of 'expertise' to include experience gained from parenting" (Nash, 1990, p. 323). The intent of Public Law 99-457 includes respecting family preferences for involvement, using family concerns to guide assessment procedures, and to meet the needs and wishes of each family (Nash, 1990). Most importantly, communication is essential for active family involvement.

Purpose of the study. The purpose of this study was to compare the therapist's interpretation of assessment of the child's fine motor development using the Peabody Developmental Motor Scale to that of the parent's perception of their child's fine motor development.

\section{Statement of the Problem. Public Law 99-457, the}

Education of the Handicapped Act Amendments of 1986 requires that family members, if they wish, become full team members and that they have the ultimate decision making authority for their child (Nash, 1990). It places the emphasis of intervention on the family unit and allows the parents or primary care giver to have a role in determining what is best for their child. Therefore, occupational therapists must shift their focus from providing child center services to "engaging in a partnership with parents" (Schaaf \& Mulrooney, 1989, p. 745). This has been a difficult transition as we are no longer viewed as the expert in 
control and the parents are no longer viewed as the passive recipients but rather the consumer of services (Bazyk, 1989). Because of the increased parental involvement, it is important to understand parent perceptions of their child in order to communicate and collaborate in writing treatment goals and objectives. However, the problem is that therapists' do not know if parent perceptions are an accurate picture of their child's abilities. If the credibility of parental perceptions could be substantiated, then perhaps, parental input would be more readily accepted and valued.

Objective and Research Questions. The objective of this study is to compare the therapist's interpretation of assessment of the child's fine motor development using the Peabody Developmental Motor Scale to that of the parent's perception of their child's fine motor development. The following research question was answered: Is there a significant difference between the therapist's interpretation of assessment using the Peabody Developmental Motor Scale to the parent perception of their child's fine motor development?

Significance of the Study. The Education of the Handicapped Act Amendments of 1986 (Public Law 99-457) identifies occupational therapy as a primary early intervention service for infants and young children and their families (Schaff \& Mulrooney, 1989). Compliance with 
the law requires that occupational therapists place more emphasis on developing a team approach with the family. By examining and comparing parental perceptions to the therapist's interpretation of a standardized developmental assessment, a measure of the accuracy of parental perception can be achieved. If parental perceptions are found to be accurate, that is highly correlated with a standardized assessment, then therapists could proceed with more confidence in soliciting parental input for not only assessment but other aspects of treatment planning such as goal writing and treatment implementation as indicated in Public Law 99-457.

Assumptions. 1. It is assumed that the person filling out the questionnaire is the parent or the primary caretaker.

2. The parent or primary caretaker filling out the questionnaire is able to read and understand the questions regarding their child's fine motor abilities.

3. The parent or primary caretaker is answering the questions to the best of their knowledge, without actually "assessing" their child but answering on the perceptions and beliefs that they have of their child.

4. There will be no significant maturation between the time the Peabody Developmental Motor Scale is given to the time the parent or primary caretaker answers the questionnaire. 
5. The Peabody Developmental Motor Scale (Fine Motor Scale) is reflective of the child's best abilities and is correctly measured, scored, and interpreted by the therapist administering the test.

6. Finally, it is assumed that the translation of the questionnaire from English to Spanish is accurate and understood by the parent or primary caretaker. 


\section{Literature Review}

Early intervention is the term used to describe "multidisciplinary services provided for the developmentally vulnerable or disabled children from birth through age three years and their families. These programs are designed to enhance child development, minimize potential delays, remedied existing problems, prevent further deterioration, limit the acquisition of additional handicapping conditions and/or promote adaptive family functioning" (Meisels and Shonkoff, 1990, p. 16). The Education of the Handicapped Act Amendment of 1986 (Public Law 99-457) places emphasis on family centered early intervention programs. Part H, Early Intervention Program for Infants and Toddlers with Disabilities, emphasizes the essential role of the families in facilitating the growth and development of their children with special needs (Hanft, 1988). The law is designed to promote family involvement in assessment and implementation, encouraging the parent not only to be aware of services provided but to be a part of them.

Parental Involvement. Over the years, occupational therapy has evolved with regards to the importance of parental involvement. Moersch (1989) summarizes that the 1947 Willard and Spackman textbook of occupational therapy mentioned parents only three times. By 1978, in the fifth edition, Moersch (1989) cites Tiffany (1978) that 
"therapists in acute pediatric settings could expect to spend 50 percent of their time working with adults under stress--the patients' families" (p. 428). Tiffany (1978) also writes that the entire family of the child with cerebral palsy should be a member of the treatment team. More recently, Anderson and Hinojosa (1984) concluded from their study that "The occupational therapist's time spent with parents may be more important and therapeutic than time spent in direct treatment of the child" (p. 460). Traditionally, the therapist evaluated, assessed, and developed the treatment goals and plan with minimal input from parents. The parents were then responsible for following through with a home program along with their other responsibilities. Moeller (1986) provides a clear example of one parent's frustration:

"I have three children at home, all preschool age, and my youngest is handicapped. It takes all the physical energy I have to cope. I was supposed to work on his fine motor skills at home for an hour each day between therapy sessions. I felt so inadequate that I didn't have the nerve to tell the teacher I couldn't even begin to find the extra time." (p. 158)

Moeller quotes another parent:

"...'You know the job, you're the expert-you make it work'. I get tired of trying to be so many different 
people and be good at all of them...wife, mother, special mother, employee. I can't make it all work, and I don't pretend to know how.... I expect her to make my life easier, not harder." (p.159)

As such, the parents were viewed as the recipients of services, rather than as partners in the child's intervention program (Case-Smith \& Nastro, 1993; Bazyk, 1989). Parents were also judged according to their participation in their child's therapy. As therapists, parents were thought of as a homogeneous group and were expected to follow through with the same enthusiasm, regardless of the parent's situation in the home (Bazyk, 1989). If they did not follow through, it was assumed that the parents were non-compliant (Cadman, Shurvell, Davies, \& Bradfield, 1984). Assumptions were often made that noncompliant parents were less reliable and therefore less efficient in becoming a contributing member of the team.

Family Centered Therapy. The focus has now shifted to family centered therapy which is guided by the needs of the entire family (Bazyk, 1989). The family, as part of the early intervention team, is to decide on the extent, type, and priorities of intervention (McGonigel, Kaufmann, \& Johnson, 1991). Collaboration between the parent and the therapist is critical for family centered therapy. When this is established, parents and therapists contribute equally to assessment, problem solving, and decision making 
(Case-Smith, Nastro, 1993; Bazyk, 1989). Collaboration means a two way sharing of information to successfully identify the best intervention activities for the child and the family (Bazyk, 1989). Although this is supported in literature, it is not always realized in practice. Therapists' continue to have difficulty giving up their authoritative role especially in assessment and evaluation. Moeller (1986) describes a parental point of view: "It is only natural that we parents view professionals as experts, and naturally we assume they know what programs are best for our child.... The parent is often reluctant to argue or disagree with the professionals.... professionals need to keep in mind that parents are most understanding of their child's needs, and to let parents know they value their unique insights." (p. 157) Therapist must listen and hear what the parents feel about their child's abilities and to keep these in mind when developing goals. After all, what is important to the parent may not be what is important to the therapist, but it may just be a broader expectation which can be broken down into smaller steps. Expectations and perceptions may differ but the desired outcomes are generally similar. Ultimately, the parent must feel that their expectations are important and considered valuable. Assessment and Parental Report. Assessment is the process of gathering information in order to identify strengths and weaknesses and to interpret the findings for 
program planning (Huber \& King-Thomas, 1987). The testing is just one part of the procedure. Gathering information from parents, teachers, and other professionals as well as observing the child in his environment are other important aspects of assessment (Huber \& King-Thomas, 1987).

Public Law 99-457 mandates that family should be an active member of the multidisciplinary team and this includes the area of assessment. Many studies have been done on the accuracy of parental report. In one early study by Jensen \& Kogan, (1962), their findings indicated that children who were handicapped both physically and intellectually were more likely to be over-rated by their parents and that younger children were more likely to be over-rated than older children.

Zuk (1959), reported that there was a positive bias when children were relatively normal in motor skills but this bias was not found in parents with retarded children who had delayed motor functions.

More recently, the study by Fleischer, Belgredan, Bagnato, \& Ogonosky (1990) supported judgement based assessment. They cite Simeonsson, Huntington, \& Parse, (1980), "A major purpose of assessment is to attain reliable, valid, and communicable descriptors of a child's development that will provide a basis for describing and documenting appropriate treatment [and that include] the insights, knowledge, and judgements of parents and staff who 
work directly with such children" (p. 64). In their review of literature, they found that there were many studies that had a high correlation between parent and professional ratings. But, when the actual estimates of status were examined, parental ratings tended to be high relative to professionals (Fleischer et al., 1990; Sheehan, 1988). Many attribute this to parent overestimation but Gradel, Thompson, and Sheehan (1981) have a different theory. They suggest that the differences may be due to professional underestimation, rather than parental overestimation. Blancher-Dixon \& Simeonsson (1981) give the alternative that the differences should be considered irrelevant-they suggest that we "...view correspondence as shared perspectives and discrepancies as the result of different perspectives" ( $p$. 70). Dunst, Trivette, \& Deal, 1988 and Sexton, Thompson, Perez, \& Rheams (1990) share views that the value of the therapist and family perceptions is the intent and spirit of family empowerment.

The results from Bricker \& Squires (1989a, 1989b) study reported a substantial agreement between the parent's report on the Infant Monitoring Questionnaire to that of the professional using the Gesell, Bayley, and Stanford-Binet. They found that the parent report was consistent over time as well as professional agreement with the parental report over time. In summary, the authors felt that using the questionnaire was appealing in that it involved parents in 
the assessment of their child and that parents could be sensitized to early development which may establish appropriate expectations. And finally, asking for parental participation conveys that they are important in the screening process and should be included.

In a similar study by Bricker (1991), it was found that the mothers who filled out the Infant Monitoring Questionnaire were more accurate observers and had more agreement with the professional assessment than the mothers who did not fill out the questionnaire. The differences between the two groups of mothers were significant for the Bayley Mental Scale and the Psychomotor Scale, with greater differences in motor items.

The purpose of a study by Parush \& Clark's (1988) was to "develop a reliable instrument that would assess a mother's knowledge about the sensory development of infants and her self perceived influence on the development of her child" (p. 11). The findings provided evidence that the items on the questionnaire were internally consistent, with high correlations between the mother's knowledge and their perceptions of the degree of influence they had on the development of their child. The researchers interpretation of the results was that "the more knowledge the mother possesses about the sensory capacity of her child, the more empowered she feels to influence her child's development or vice versa" (p. 14) 
Miller and Davis (1992) designed a study to clarify the findings from the parent's beliefs literature concerning parental accuracy. As in other studies, (Miller, 1986; Miller, Manhal, \& Mee, 1991), they found that the mothers were above chance but far from perfect in predicting their child's cognitive abilities, preferences, and traits. The teachers were as accurate as the parent in predicting cognitive performance but less so in preference and personality items. In reviewing the literature, Miller, et al. (1992) found that there is little evidence supporting the assumption that parents are any better at predicting their own children's abilities than children in general. More importantly, they also found that when parents do make errors, they generally tend to overestimate what their child is able to do.

Miller, (1988) reviews the literature and notes that the common goal of studies looking at special populations and parental beliefs is determining whether parents can provide useful diagnostic information about their child. He found that there are more and more screening tools utilizing parental report. In looking at accuracy, he found the tendency towards underestimation was found in studies that focused on few milestones of infant development, and that accuracy is greater for language milestones than for perceptual milestones. In his review of the literature for special populations, he found that many of the studies had 
similar conclusions and that parents had a general knowledge that their child would have a lower cognitive ability. When these parents made errors in their child's ability there was also a tendency for an overestimation of ability.

Correlations between parental estimate and child's ability were comparable to the non-handicapped population. In his review, two suggestions emerged. One, is that parental accuracy increases as the child gets older because of the feedback the parent receives regarding their child's abilities (Anton \& Dindia, 1984). Second, that parents have an increasingly realistic expectations because of the consistent feedback that they receive while the child is in school (Entwisle \& Hayduk, 1981).

In many of the studies, questionnaires were developed to determine the accuracy of parental perceptions. The Vineland Adaptive Behavior Scales, a modification of the Vineland Social Maturity Scale, uses parental report through a semistructured interview. In one review by King-Thomas \& Hacker, (1987), the parents and examiner often observe that children can do more or less of what is predicted by the earned age equivalent. They suggest that this is partly due because the Vineland is sensitive to parent bias. Kaplan \& Alatishe (1976) compared the teacher and parent ratings of the Vineland Social Maturity Scale and found that there was a significant difference between the means of the two groups with the mothers consistently reporting the social quotients 
of the children to be higher than did the teachers. They go on to suggest the importance of taking into account who is providing the information. However, Goldstein (1985) correlated the Vineland Adaptive Behavior Scale with the Bayley Motor Scale and found a strong relationship between the two tests, supporting the authors claim that the test could be used as a diagnostic evaluation tool.

Feldman, Haley, \& Coryell (1990) and Haley, Coster, \& Faas (1991) reviewed the Developmental Edition of the Pediatric Evaluation of Disability Inventory (PEDI) which is a new pediatric functional assessment that can be administered as a parental report questionnaire. It was developed to identify functional status and change in three categories. Those categories were (1) functional skill level, (2) care giver assistance, and (3) modifications or adaptive equipment used (p. 602). Haley, et al. (1991) suggest that "functional activities in children include those endeavors that support the completion of essential daily routines and that lead to the fulfillment of role expectations of parents and teachers" (p. 177). Feldman, et al. (1990) reviewed the concurrent and construct validity of the Developmental Edition of the PEDI. The correlations ( $r$ $=.70-.80)$ suggest that the PEDI when compared to the Battelle Developmental Inventory Screening Test (BDIST) can be a useful standardized assessment for the description of functional status of young children and support further 
research for the final version. The authors suggest that the value of the assessment of developmental milestones cannot be overlooked, but that assessment should not be soley based on milestones. "Measuring progress in terms of a child's functional status is often in greater accordance with the physical therapist's and the family goals than discrete skills" (p. 610).

The Pediatric Evaluation of Disability Inventory (PEDI) Manual (1992) provides an overview of recommended methods for administration of the PEDI. The main goal is to obtain an accurate description of the child's functional abilities. It is believed that this assessment should be "completed by a person or group of persons who are familiar with the child's typical performance in the domains surveyed by the instrument" (p. 77). The PEDI is looking for the child's typical performance and suggest that those completing the assessment, observe on several occasions. Typically, the parents and the professionals providing the range of services are most commonly utilized. With the parents, a structured interview is generally used to ensure that all the necessary information is obtained for scoring. Part I, Functional Skills, may be given to the parents to fill out independently, however, the professional should review the questions with the parents after completion. Parts II and III have more detailed questioning and the authors strongly recommended that the professional follow the structured 
interview. This is a vital part of the training in administration of the PEDI.

Sexton, Thompson, Perez, \& Rheams (1990) reviewed the literature and summarized the following regarding the inclusion of parent reported developmental assessment data: Many early intervention professionals have noted practical advantages of using parents as data sources: (a) Collection of data based on parental judgements can be cost efficient; (b) early involvement of parents in the assessment process facilitates professional-parent collaboration; (c) parents who help decide intervention targets may be more likely to participate actively in implementing prescribed interventions; and (d) by including parental assessment data professionals maximize the ecological validity of overall assessment results, and conclusions are more likely to generalize across environments, because data from several environments are considered in reaching conclusions. (p. 81)

The focus of their study was to examine the "congruence between professional and parent child development assessment data for children enrolled in early intervention programs" (p. 82) using the Battelle Developmental Inventory (BDI) and the Developmental Profile II (DP). They asked three questions: 1) Do parental judgements and results obtained from direct testing place the children with handicaps in the 
same order with respect to developmental estimates?, 2) Are there differences between parental estimates and direct testing?, and 3) Is there a relationship between ecological variables (i.e., mother's education level, maternal stress, family resources)? For the first question, results indicated the two variable sets shared extraordinary amounts of variance. The results for the second question suggested that parental estimates of development were higher than those obtained on the Battelle. And lastly, results for the third question suggested that the five predictor variables did not do an accurate job of explaining the differences. In summary, the authors strongly believe that professionals should not exclude parental judgements from assessment. In addition, they believe that their results indicate the importance of utilizing many sources, including parents, as a basis for early collaboration with families.

Although many of the studies reviewed indicated that parent estimate is often overestimated, most suggest the inclusion and utilization of parent report in addition to direct testing.

With the changes in laws and public policy as well as the increase in parents becoming stronger advocates for their children, it is not surprising that no literature was found supporting professionals to exclude parental report. Many things influence parent perception. Frey, Fewell, \& Vadasy (1988) examined how different factors influenced 
parent and child adjustment outcomes. They found that adjustment was related to the ability of the child to communicate and to the child's sex. Parents of girls were better adjusted than parents of boys, and this is consistent with other studies which they cite although no further discussion was provided. Satisfaction with support was also related to parental adjustment. In their discussion, they felt that an accurate description of child and parent outcomes must include the effects of the child on the parent, the effects of the parents on the child, and the effects of the parents on each other. That is, the child must be viewed as a component of the family unit or system. It is suggested that professionals be open to whatever level of involvement a family can accommodate; after all, many changes occur in the family over time and parents go through many stages in adjusting to having a child with special needs (Nash, 1990).

Although the literature supports parental reports most suggest that further research is necessary to continue validating the family centered approach to early intervention. Specifically, the literature is inconclusive as to whether or not parents or therapist over or under estimate, hence further research is needed to clarify the accuracy of parental perceptions. 


\section{$\underline{\text { Research Procedure }}$}

Subjects. Fifty eight children who were enrolled in the Debbie School Early Intervention Program and their parents or primary caretaker were recruited for the study. Consent forms were sent to 58 subjects, 42 forms were returned and 42 subjects participated in the study. Once the consent forms were collected, demographic information was obtained from the children's files. Five subjects were involved in the pilot and 37 were used for the current study. The children had varying disabilities, from mild to severe involvement, and were receiving occupational therapy at the time of the study.

Description of the pilot study subjects was as follows: The age range for the four males and one female were 13 to 37 months with a mean age of 23 months. Two of the children had cerebral palsy and three of the children had developmental delays. The parent answering the questionnaire were all mothers and their ages ranged from 27 to 44 with a mean age of 33.8 years. Of this group, one mother did not graduate from high school, three graduated from high school, and one earned a graduate degree. With regards to racial origin, three were African American, one was Caucasian, and one was Hispanic.

Description of the current study was as follows: The age range for the children of the study was 10 to 45 months 
with a mean age of 26.67 months. There were 21 males (56.8\%) and 16 females (43.2\%). Thirty six mothers and one father filled out the questionnaire. The age ranges for the mothers were 21 to 48 years with a mean age of 31.9 years. With respect to highest educational level attained by the mothers, six (13.98) did not complete high school, 24 (63.9\%) completed high school, and seven (19.4\%) graduated from college. Racial origins of the subjects was 13 (35.1\%) African American, 16 (43.28) Hispanic, two Caucasian (5.48), and $\operatorname{six}(16.2 \%)$ Other. The diagnoses were broken down into the following categories: Cerebral Palsy (10), Down Syndrome (9), Genetic other than Down's Syndrome (9), Spina Bifida (2), Developmental Delay (3), and Other (4). Of the 42 participating families (the pilot and current study), 26 used English as their primary language in the home with 16 using Spanish as their primary language.

Design. A comparison group survey design was used for the study. A survey is a "method of collecting information directly from people about their feelings, motivations, plans, beliefs, and personal, educational, and financial background" (Fink \& Kosecoff, 1985, p.13). A commonly used survey is that of a questionnaire. A questionnaire can be designed to be self explanatory and self administered, without supervision (Fink \& Kosecoff, 1985). This design was chosen for this study because the information, that is, the parent's or primary caretaker's perceptions, is what was 
being studied and compared to the therapist's assessment of their child.

Method. A letter, written in their primary language, was sent home explaining the study and the importance of their role within this project. If they choose to participate, the informed consent was signed and returned to the Debbie School (Appendix A). Once the informed consent was returned, the subject and parent would be assigned a data base number to be used for confidentiality purposes. During the month of December, each subject was given the Peabody Developmental Motor Scale (PDMS), as part of their standard therapy for re-evaluation by this therapist. The evaluation was given under standardized methods and scored accordingly. The scoring was based upon the numbers 0,1 , and 2. The 0 means that the child did not demonstrate the task, the 1 means that this task is emerging and the 2 means that the child demonstrated this task correctly. The questionnaire was then sent home along with a cover letter explaining the directions and guidelines for answering the questions (Appendix B). The questionnaire was written in the parent or caretaker's primary language spoken in the home. The questionnaire was individualized to each child in that the therapist sent sections of the questionnaire rather than the complete questionnaire. For example, once the basal and ceiling level was determined under standardized methods, the therapist gave the parent or caretaker two 
sections below the basal and two sections above the ceiling level. This would decrease the amount of time the parent or caretaker had to spend answering the questions and it would not disclose the therapist's findings. The questionnaire would be based on the PDMS, written in layman's terms and would be answered by the parent using the same scores of 0 , 1, and 2. It was emphasized that they were to answer the questions using their best guess or judgement, without trying the task with their child. Once the questionnaires were returned, the answers were tallied and compared to the therapist assessment scores on the Peabody Developmental Motor Scale, Fine Motor Section.

Instrumentation. The Peabody Developmental Motor Scale (Fine Motor Scale) is used at the Debbie School. This instrument was chosen by the therapist because it is part of the child's standard therapy assessment of progress.

Many assessment tools are available and have varying methods for obtaining information. The Peabody Developmental Motor Scale (PDMS) is regularly used in early intervention settings. Palisano \& Lydic (1984) provide an analysis of the test and conclude that it offers a number of advantages. It is standardized, measures development up to 7 years of age, has a sufficient number of items at each age level, and offers a variety of ways to present the data. They also feel the PDMS is appropriate for use with handicapped children, although more research is needed in 
this area. Test-retest for fine motor is .80 and interrater reliability for fine motor is .94 . These results are well within accepted limits and indicate good test stability and replicability (Palisano \& Lydic, 1984; King-Thomas \& Hacker, 1987). Validity studies of the Fine Motor section show significant correlations to the Bayley Motor and Mental Scales and the Assessment of Sensorimotor Integration in Preschool Children (King-Thomas \& Hacker, 1987). Construct validity was examined and statistically significant gains were obtained for all ages for the fine motor scale. Concurrent validity was examined and significant correlations were obtained between the Bayley Mental and Motor Scale and the PDMS Fine Motor Scale. Those correlations are reported in the manual. Correlations for the Bayley Motor Scale and the PDMS are .78 at the .001 level and .36 at the .02 level for the Bayley Psychomotor Scale.

A questionnaire was developed by this author based on the questions of the Fine Motor section of the Peabody Developmental Motor Scale (PDMS). Each question was written in an attempt to keep the developmental "terminology" to a minimum to enhance the parents comprehension of the questions. The questions were written to encourage the parent to answer the questions to the best of their ability, without actually assessing their child. The questions were divided into 11 sections based on the same progression of 
the PDMS. Age ranges were not provided on the questionnaire and sections were given to the parent or primary caretaker based on the basal and ceiling levels at time of therapist assessment, as previously described. The scoring of $0,1,2$ is based on that of the PDMS. The noted difference between the standard scoring of the PDMS and the parent questionnaire score was a score of 1 . A score of 1 for the standard scoring refers to an emerging skill. Since it was anticipated that this might be a difficult concept for parents to comprehend, the description for a score of 1 on the parent questionnaire read: "I think my child can do this or I haven't seen my child do this at this time." In addition, male and female versions were provided to eliminate sexist language and to reduce any possible confusion (See Appendix B). A pilot study was completed to assess the clarity of the parental questionnaire. The pilot was completed on the children in the high risk program at the Debbie School. These children are part of the early intervention program but are mainstreamed into the infant and toddler day care program based at the Debbie School. It was believed that these select children and their parents would be a good representation of the children within the early intervention program.

Statistical Analysis. A comparison between parent perception and therapist assessment was done using paired ttests. "The t-test allows one to compare the average views 
of two groups to determine the probability that any differences between them are real and not due to chance" (Fink \& Kosecoff, 1985, p.75). Analyses of variances (ANOVA) were also calculated on demographic variables to determine if any one factor was significant.

\section{Limitations of the Study}

One limitation of the study is that it cannot be generalized to the population. The subjects are a small sample of Dade County, Florida. The ethnicity of this population was primarily Hispanic and African American with low socioeconomic status.

A second limitation is that the therapist gives the PDMS in English to all the subjects, therefore not speaking the primary language of 16 of the subjects. However, with this aged population, very little verbal communication is required in the administration of the PDMS. In addition, this administrator does possess a limited ability to converse in Spanish, the alternate primary language.

A third limitation of the study is that the parent or primary caretaker may be tempted to "test" the child in order for the child to do better on the questionnaire. This was stressed to each parent and/or caretaker repeatedly, however, the therapist was unable to monitor the actual completion of the questionnaire in the home. 
$\underline{\text { Results }}$

The purpose of the study was to compare the therapist's interpretation of a standardized assessment of the child's fine motor development using the Peabody Developmental Motor Scale (PDMS) to that of the parent's perceptions of their child's fine motor development.

pilot study. The data for the $\underline{t}$-test and correlations are presented in Table 1. Means and standard deviations for the scaled scores and developmental age scores for the parents and therapist are provided. All Pearson productmoment correlations were high and significant at the .01 level. Results of the $\underline{t}$-tests for scaled scores and developmental age scores yielded no significant differences between the therapist and mother. Thus, the therapist's assessment of the child was similar to that of the parent's perception of their child's fine motor abilities. 
Table 1

Differences Between Therapist Assessment and Mother's Perceptions of Child's Fine Motor Development

Group

$M \quad S D \quad \underline{n}$

value $\quad$ value

Scaled Score

Therapist

$460 \quad 38.516 \quad 5$

$.992 * \quad .20$

Mother

$459 \quad 28.302 \quad 5$

Developmental

Age Score

Therapist

$18 \quad 9.165 \quad 5$

Mother

$17.2 \quad 6.496 \quad 5$

${ }^{*} \underline{p}<.01$, two-tailed 
Pilot Study Compared to the Current Study. In comparing the pilot study results to the current study results, the t-test yielded no significant differences between the two groups. The data for the $\underline{t}$-test are presented in Table 2 .

Table 2

Comparison of Pilot Study and Current Study in Relation to Developmental Age Scores and Scaled Scores

Group

$\mathrm{n}$

$M(a)$

SD

$\mathrm{va} \stackrel{\mathrm{t}}{\mathrm{l}} \mathrm{ue}$

Developmental

Age Score

$\begin{array}{lcccc}\text { Pilot } & 5 & .8000 & 2.775 & \\ \text { Current } & 37 & .8378 & 3.508 & -.03\end{array}$

Scaled Score

$\begin{array}{lcccc}\text { Pilot } & 5 & 1.0000 & 11.06 & \\ \text { Current } & 37 & .3243 & 25.89 & .10\end{array}$

$\underline{\mathrm{p}}<.01$, two-tailed

Note: (a) - The mean is based on subtracting the therapist scaled score from the parents scaled score for each child 
Current study. Pearson product-moment correlations were computed for scaled scores and developmental age scores between the therapist and parent. They were found to be high and very significant at the .01 level. Paired $\underline{t}$-test were computed on the two groups and yielded no significant differences between the therapist assessment and the parental perceptions of their child's fine motor development. The data is presented in Table 3 . These results indicate that parental perception of their child's fine motor abilities is consistent with the therapist's objective assessment using the PDMS. 
Table 3

Differences Between Therapist Assessment and Parental Perception of the Child's Fine Motor Development

\begin{tabular}{|c|c|c|c|c|}
\hline Group & $\mathrm{n}$ & $M$ & SD & value \\
\hline
\end{tabular}

Scaled Scores

$\begin{array}{llllll}\text { Therapist } & 37 & 430.27 & 53.16 & & \\ & & & & .882 * & .08 \\ \text { Parent } & 37 & 429.94 & 40.28 & & \end{array}$

Developmental

Age Scores

Therapist

37

$12.97 \quad 7.98$

$.899 *$

1.45

Parent

37

12.13

7.30

$* \underline{p}<.01$, two-tailed 
In addition, Analyses of Variances (ANOVA) were computed to explore whether similarities or differences between developmental age scores of therapists and parents could be attributed to particular child and/or family characteristics. As evident in Table 4, the results did not reveal any significance when testing for main effects of maternal age, maternal education, ethnicity, and chronological age of child. However, test results were significant when testing for main effects of gender and number of children in the household. 
Table 4

Comparison of Demographic Variables

Group

$\mathrm{n}$

Mean

$\underline{F}$

Squares

Maternal

Age 36

6.5722

.5823

Maternal

Education

36

30.8400

3.0970

Ethnicity

$33(a)$

3.168

.2590

Chronological

Age

36

33.9385

3.0759

Gender

36

60.6310

6.9200 *

Number of

Children

36

42.4420

4.1480 *

${ }^{*} \mathrm{p}<.05$

Note: (a) Fewer subjects included because information not available for all subjects 


\section{Chapter V}

Discussion

Historically, occupational therapists have relied upon objective data from "test" for their assessments with little consideration of parental input. Much of the research has suggested that parents often provide higher estimates of developmental levels than those obtained by professionals (Sexton et al., 1990). Sheehan (1988) summarized that in reviewing 24 studies, $75 \%$ suggested that parents (usually mothers) rated their children significantly higher than did professionals. However, Public Law $99-457$ has shifted the focus from child centered therapy to family centered therapy and has mandated the involvement of family in developing a plan of treatment, including assessment procedures. For these reasons, this study was conducted to compare the therapist's interpretation of a standardized assessment and the parental perception of fine motor abilities of the children enrolled in an early intervention setting. More specifically, this study was designed to address the following question: Is there a significant difference between the therapist interpretation of assessment using the Peabody Developmental Motor Scale to the parent perception of their child's fine motor development?

The data and findings suggest that there are no significant differences between the therapist interpretation and parent perception of their child's fine motor 
development. Pearson product-moment correlations and paired t-tests were computed for therapist and parent scaled scores and developmental age scores which support that there were no significant differences. Refer to Tables 1 through 4 for actual data. Results indicated that the therapist and parent are uniform in their view of the child with regards to fine motor development.

Contrary to this therapist's original hypothesis, parents did not significantly over or underestimate their child's fine motor abilities. In general, the findings of this study are in agreement with Bricker \& Squires (1989a, 1989b) and Sexton et al.(1990). Parents may be an accurate reporter of their own children's abilities as they see their children every day and observe them in their daily routine. In addition, Analyses of Variances were computed on the demographics in order to test for significance between the two groups. Test results approached significance with only two of the six factors.

The test for main effects of gender and number of children in the household were significant (Table 4). For gender, the therapist rated the male children higher than did the mothers and for females, the reverse was found. The therapist rated female children lower than did the mothers. This significant $\underline{F}$ value is difficult to interpret. However, Frey et al. (1988) reported consistency with other research that parental adjustment is more difficult when the 
child is male although this is not discussed further. Perhaps higher expectations are held for female offspring than for male offspring in the area of fine motor abilities. It would be interesting to study the gender factor with a gross motor assessment to see if the gender stereotype reverse expectation were true. This may also explain the gender effects found in the current study.

The significant $\underline{F}$ value on number of children in the household is less difficult to interpret. Households with more than 2 children were more accurate in their perceptions than households with 2 children or less. If other children are in the home, the parents frame of reference may be more accurate as they may compare their children to determine if they followed along the same developmental sequence. It should be noted with both factors, gender and number of siblings, that the population sample was small and with such a small sample size, significant differences can be due to chance only.

Several factors peculiar to this study may have confounded results. First, the children and parents involved in this study were already familiar with the evaluator and rapport had been established prior to the study. Contact with parents occurred on a regular basis, establishing a positive communication pattern and providing updates on their children's abilities over a varying amount of time ( 6 to 24 months). This may have provided parents 
with a general understanding of what to expect along the developmental sequence therefore, results may be more closely correlated between this particular evaluator and this group of parents. Less familiar parent/therapist dyad could produce lower correlations.

Results indicate that the questionnaire was understood by parents and the questions were answered to the best of the parent's abilities as the correlations were very significant. Several of the test items on the PDMS use skills that are seen in the home, school, and therapy environment. The strong correlations between the standardized assessment and the questionnaire could be specific to the choice of the assessment, the PDMS. Following this logic, those assessments that utilize everyday items would demonstrate a strong correlation to parental perception. Conversely, if the assessment utilized items unfamiliar to the home or family environment, the correlation between the standardized assessment and parental perception may not be as strong.

\section{Conclusions}

The need for occupational therapy services in pediatrics, particularly early intervention, is increasing steadily due to several factors. The expansion of technology in the Neonatal Intensive Care Units means an increasing number of infants survive the initial crisis. Federal laws mandate early intervention treatment be 
provided to the birth to three population at no cost to the parent/guardian. The increase number of children born at risk for delays due to environmental toxins such as crack cocaine and alcohol. This increased demand for services has significance in terms of implementation of services. Parental input can be utilized to facilitate assessment which empowers them as strong advocates for their children with regards to treatment and intervention. By acknowledging their expertise we empower the parent, therefore, enhance the relationship between the therapist and the parent. Parents are more likely to voice opinions, concerns, and/or relevant issues if they feel they are valued as a team member. By establishing this early on, the rapport or mutual respect attained may carry over into goal writing and treatment implementation. If parents have an accurate perception of their child's abilities, then realistic goals are more likely to be identified and most importantly, compliance and/or participation in implementation is more likely to occur.

Therapists must look closely at their attitudes towards parent involvement. Many therapist go into the field for the hands on clinical approach, but Public Law 99-457 is shifting that focus with early intervention to a more consultative, family interaction model. Masin (1992) writes, "Therapist have intensive studies in normal development and anatomy, physiology, and biological sciences 
to understand how the body develops and moves (p. 4). Schooling for therapist is more focused towards clinical approaches with little background on dealing with family issues. Therapist are no longer thought of as the "authority" in early intervention but are expected to become a team member along with the parent. Parental education is becoming increasingly important and using questionnaires, such as the one utilized in this study or in Bricker et al. (1989a, 1989b), may help to establish more appropriate expectations.

Utilizing questionnaires may also convey to the parent that their input is valuable and important in the evaluation, therefore improving the professional-parent relationship, and encouraging mutual respect. Utilizing a questionnaire can also be cost effective in terms of the increasing number of children needing evaluations and the shortage of therapist available. Sexton et al. (1990), Bricker et al. (1989a, 1989b) supports the cost effectiveness of using a questionnaire as a screening tool. With the direction of health care and the rising cost, the use of parental report as a substitute for actual therapist assessment may be considered in the future. This research suggest that the questionnaire in this study may be used as an adjunct for screening but not as a substitute for a therapist's assessment. Blending the knowledge of the therapist with the reliable parental perception will yield 
the most comprehensive assessment.

Recommendations for Further Research

Some potential areas for future research include an investigation of the amount of time the child is in early intervention and how this familiarity affects parental perception of their child's fine motor ability. This author speculates that less familiarity will yield less significant correlations between therapist assessment and parental perception. A study to determine whether or not there is a predictable correlation between the emotional stages of acceptance that parents experience after the birth of a handicapped child and the accuracy of parental perceptions of their child's fine motor abilities. Generalizability of the study could be improved by replicating with a larger sample size. An exploration of the therapist's attitudes towards parental involvement and how the interaction between the parent and therapist affects parental perception could prove to beneficial. The methodology of this study could be improved by having the parent "assess" their child rather than self report and compare parental assessment to therapist assessment of the child. Lastly, identify if there are any differences in the perceptions of parents in the home based program of early intervention and the parental perceptions of the children in the center based program of early intervention. Summary 
In summary, therapist have traditionally given little credence to parental input based on the belief that the information would be inflated, that is, an overestimation of their child's true abilities. The findings of this study suggest that parents possess an accurate appraisal of their child. This study lends support to the use of parental reports to assist in developing and implementing treatment. With the shift to family centered therapy, parents can be a useful and cost effective tool when screening, evaluating, and ultimately establishing appropriate goals and objectives for their child. 


\section{References}

Anderson, J. \& Hinjosa, J. (1984). Parents and therapists

in a professional partnership. American Journal of Occupational Therapy. 38, 452-461.

Anton, B. S., \& Dindia, G. (1984). Parental perception of cognitive abilities of children with cerebral palsy. Psychological Reports. 54, 987-990.

Bazyk, S. (1989). Changes in attitudes and beliefs regarding parent participation and home programs. American Journal of Occupational Therapy. $\underline{43}(11), 723-$ 728 .

Blacher-Dixon, J., \& Simeonsson, R. J., (1981). Consistency and correspondence of mothers' and teachers' assessment of young handicapped children. Journal of the Division for Early Childhood. 주 64-71.

Bricker, D., \& Squires, J., (1989a). The effectiveness of parental screening of at-risk infants: The infant monitoring questionnaires. Topics in Early Childhood Special Education. $9(3), 67-85$.

Bricker, D., \& Squires, J., (1989b). Low cost system using parents to monitor development of at-risk infants. Journal of Early Intervention. 13(1), 50-60. Cadman, D., Shurvell, B., Davies, P., \& Bradfield, S., (1984). Compliance in the community with consultants' recommendations for developmentally handicapped children. Developmental Medicine and Child Neurology. 
$\underline{26}, 40-46$.

Case-Smith, J., \& Nastro, M. A., (1993). The effect of occupational therapy intervention on mothers of children with cerebral palsy. American Journal of Occupational Therapy. $\underline{47}(9), 811-817$.

Dunst, C. J., Trivette, C. M., \& Deal, A. G., (1988). Enabling and empowering families-principles and guidelines for practice. Cambridge, Mass: Brookline Books •

Entwisle, D. R., \& Hayduk, L. A., (1981). Academic Expectations and the school attainment of young children. Sociology of Education. 54, 34-50.

Feldman, A. B., Haley, S. M., \& Coryell, J., (1990). Concurrent and construct validity of the pediatric evaluation of disability inventory. Physical Therapy. $\underline{70}(10), 602-610$.

Fink, A., \& Kosecoff, J., (1985). How to conduct surveys-A step-by-step quide. London, England: Sage Publications.

Fleischer, K. H., Belgredan, J. H., Bagnato, S. J., \& Ogonosky, A. B., (1990). An overview of judgementbased assessment. Topics in Early Childhood Special Education. $10(3), 13-23$.

Frey, K. S., Fewell, R. R., \& Vadasy, P. F., (1988). Parental adjustment and changes in child outcome among families of young handicapped children. Topics in 
Early Childhood Special Education. $\underline{8}(4), 38-56$. Goldstein, D. J. (1985). Accuracy of parental report of infant motor development. Perceptual and Motor Skills. $\underline{61}, 378$.

Gradel, K., Thompson, M. D., \& Sheehan, R., (1981).

Parental and professional agreement in early childhood assessment. Topics in Early Childhood Special

Education. $1(3), 31-39$.

Haley, S. M., Coster, W. J., \& Faas, R. M., (1991). A content validity study of the pediatric evaluation of disability inventory • Pediatric Physical Therapy. $3(4), 177-184$.

Haley, S. M., Coster, W. J., Ludlow, L.H., Haltiwanger, J. T., \& Andrellos, P. J., (1992). Pediatric evaluation of disability inventory (PEDI): Development, standardization and administration manual. Boston: EDI Research Group.

Hanft, B., (1988). The changing environment of early intervention services: Implications for practice. American Journal of Occupational Therapy. $\underline{42}(11), 724-$ 731 .

Huber, C. J. \& King-Thomas, L., (1987) . The assessment process. In L. King-Thomas \& B. Hacker, (eds.) $\underline{A}$ Therapist's Guide to Pediatric Assessment. Boston, Mass.: Little, Brown and Company. Jensen, G. D. \& Kogan, K. L., (1962). Parental estimates of 
the future achievement with cerebral palsy. Journal of Mental Deficiency Research. ㅁ, 56-64.

Kaplan, H. E. \& Alatishe, M., (1976). Comparison of ratings by mothers and teachers on preschool children using the vineland social maturity scale. Psychology in the Schools. $13(1), 27-28$.

King-Thomas, L. \& Hacker, B., (1987). A therapist's guide to pediatric assessment. Boston, Mass: Little, Brown and Company.

Masin, H. L., (1992). Perceived maternal knowledge and attitudes toward physical therapy during early intervention in two ethnic groups. Unpublished doctoral dissertation. University of Miami, Florida. McGoniel, M., Kaufmann, R. K., \& Johnson, B. H., (1991). Guidelines and recommended practices for the individualized family service plan. Bethesda, MD: Association for the Care of Children's Health. Meisels, I.\& Shonkoff, J., (1990). (Eds.) Handbook of early childhood intervention. Cambridge: Cambridge University Press.

Miller, S. A., (1986). Parents' beliefs about their child's cognitive abilities. Developmental Psychology. 22, $276-284$.

Miller, S. A., (1988). Parents' beliefs about children's cognitive development. Child Development. 59, 259285 . 
Miller, S. A. \& Davis, T. L., (1992). Beliefs about children: A comparative study of mothers, teachers, peers, and self. Child Development. 63(5), 1251-1265. Miller, S. A., Manhal, M., \& Mee, L. L., (1991). Parental beliefs, parental accuracy, and children's cognitive performance: A search for causal relations. Developmental Psychology. 27(2), 267-276. Moeller, C. T., (1986). The effect of professionals on the family of a handicapped child. In R. R. Fewell \& P. F. Vadasy (eds.) Families of handicapped children: Needs and supports across the life span. Texas: Pro-ed. Moersch, M. S. (1989). Parents and family involvement. In P. N. Pratt \& A. S. Allen (eds.). Occupational therapy for children. Baltimore: The C.V. Mosby Company. Nash, J. K. (1990). Public law 99-456: Facilitating family participation on the multidisciplinary team. Journal of Early Intervention. 14(4), 318-326. Parush, S.\& Clark, F., (1988). The reliability and validity of a sensory developmental expectation questionnaire for mothers of newborns. American Journal of Occupational Therapy. $\underline{42}(1), 11-16$. Schaaf, R. C. \& Mulrooney, L. L. (1989) - Occupational therapy in early intervention: A family-centered approach. American Journal of Occupational Therapy. $\underline{43}(11), 745-754$. Sexton, D., Thompson, B., Perez, J., \& Rheams, T., (1990). 
Maternal versus professional estimates of developmental status for young children with handicaps: An ecological approach. Topics in Early Childhood Special Education. $10(3), 80-95$.

Sheehan, R. (1988). Involvement of parents in early childhood assessment. In T. D. Wachs \& R. Sheehan (eds.), Assessment of young developmentally disabled children. New York, NY: Plenum. Tiffany, E. G. (1978). Psychiatry and mental health. In H. L. Hopkins \& H. D. Smith (eds.), Willard and Spackman's occupational therapy (5th ed.). Philadelphia: JB Lippincott Company •

Zuk, G. H. (1959). Autistic distortions in parents of retarded children. Journal of Counseling Psychology. $\underline{25}, 17$. 
Appendix A 
Dear Parent,

I am conducting a study to learn more about how you, as a parent or primary caretaker, feel about your child's fine motor development. Fine motor development is how your child reaches, holds on to toys, uses their hands, and plays with toys. In order to do this I need your assistance. If you agree to take part in this study, a questionnaire will be sent to you in December. You will be asked to respond to questions about how your child uses his or her hands. This should take about 30 minutes to answer the questions. As parents, you may see your child doing things that we don't see while they are in school or therapy. If you do not wish to participate, please note that it will not affect your child's therapy or intervention in any way.

All the information will be completely confidential and the results will be written in summary form.

If you have any questions or would like a copy of the results, please feel free to call me at 547-6961.

Thank you for your valuable assistance and time. This study is being done in order to fulfill the requirements for my master's degree at Florida International University. Please make sure to sign below. Again, many thanks!

Sincerely,

Martha Belote OTR/L

Occupational Therapist

Debbie School

I, have read and I understand the above. I understand there are no known risks or benefits in my participation in this study.

$\overline{\text { Participant's signature Date }}$ 
Appendix B 
Dear Parent,

Thank you for participating in this study. These are the rules to follow in answering the questionnaire.

Please answer each question using your best guess or judgement. Do not "test" your child, I am interested in what you think your child is able to do.

Please answer all the questions. There will be a wide range of questions, some covering things too easy for your child and some too hard, so do not become upset if your child is unable to do everything that is asked.

You score each question with a 0,1 , or 2 .

$$
\begin{aligned}
& 0=\text { My child cannot do this at this time. } \\
& 1=\text { I think my child can do this or I haven't seen } \\
& \text { my child do this at this time. } \\
& 2=\text { My child can do this at this time. }
\end{aligned}
$$

Again, I would like to thank you for helping me with this study.

Sincerely,

Martha Belote OTR/L

Occupational Therapist

Debbie School 
Instructions: Please answer each question to the best of your ability. Do not try these with your child, simply try to remember what you have seen and score each according to the $0,1,2$. Some will be too easy for your child and some are beyond your child's abilities at this time. We want to see if what we see at school is what you see at home.

0: My child cannot do this at this time

1: I think my child can do this or I haven't seen my child do this at this time

2: My child can do this at this time

\section{SECTION 1}

1. When you place your finger in your

child's hand, does he close his hand?

$\begin{array}{lll}0 & 1 & 2\end{array}$

2. Does your child keep his hands closed for 10 seconds?

3. Does your child look at toys for 5 seconds?

4. When you slowly move a rattle in front of your child to one side, does he follow the rattle with his eyes? $\quad \begin{array}{llll}0 & 1 & 2\end{array}$

5. When your child's head is turned to the side, can he follow a rattle back to the front (middle) with his eyes?

6. When you place a rattle in your child's hand, does he drop the rattle within 3 seconds?

7. When your child is on his back with his head turned to the side, does he follow a rattle past the to the other side?

8. When you place a rattle in your child's hand, does your child hold on to the rattle and move it?

9. When a rattle touches on the inside of your child's hand, does he close his hand onto the rattle and hold it? 
Instructions: Please answer each question to the best of your ability. Do not try these with your child, simply try to remember what you have seen and score each according to the $0,1,2$. Some will be too easy for your child and some are beyond your child's abilities at this time. We want to see if what we see at school is what you see at home.

0: My child cannot do this at this time

1: I think my child can do this or I haven't seen my child do this at this time

2: My child can do this at this time

\section{SECTION 1}

10. Does your child hold on to toys/rattle for at least 30 seconds?

11. When your child is on his back, does he reach for a rattle?

12. When your child is on his back, does he move his head to avoid something coming towards his face?

13. When something rolls past your child, does he follow it with his eyes?

14. Does your child look at his hands? 
Instructions: Please answer each question to the best of your ability. Do not try these with your child, simply try to remember what you have seen and score each according to the $0,1,2$. Some will be too easy for your child and some are beyond your child's abilities at this time. We want to see if what we see at school is what you see at home.

0: My child cannot do this at this time

1: I think my child can do this or I haven't seen my child do this at this time

2: My child can do this at this time

SECTION 2

15. When you wave a rattle or toy in front of your child, does he move his arms and hands?

16. When you place a rattle in his hand, does your child hold and move the rattle for at least one minute?

17. Does your child reach and hold on to a rattle while sitting in your lap?

18. When you dangle a toy in front of him, does he move his hand towards the toy?

19. When he is lying on his tummy, does he reach and pull a toy towards him?

20. Does he try to pick up paper by wrinkling it?

21. When you place a block close to his hand, does he reach and grab the block using the inside of his hand?

22. When you place a block in his hand, does he bring his hands together? 
Instructions: Please answer each question to the best of your ability. Do not try these with your child, simply try to remember what you have seen and score each according to the $0,1,2$. Some will be too easy for your child and some are beyond your child's abilities at this time. We want to see if what we see at school is what you see at home.

0: My child cannot do this at this time

1: I think my child can do this or I haven't seen my child do this at this time

2: My child can do this at this time

\section{SECTION 3}

23. When you bang a cup on your child's high chair, does he try to pick up the cup by it's handle and lift it up? $\quad \begin{array}{lll}0 & 1 & 2\end{array}$

24. Does your child bang a cup on a table? $\quad 0 \quad 1 \quad 2$

25. Does your child pick up the rattle using the inside of his hand near the thumb and first 2 fingers (pointer and middle)? $\begin{array}{llll}0 & 1 & 2\end{array}$

26. Does he shake a rattle?

27. When your child picks up a block, does he use the inside of his hand close to the wrist and the last 2 fingers (ring and pinkie) to hold the block.

28. While he is holding on to one block, does he pick up a second block without dropping the first one?

29. When he is holding a block in his right hand and you place a second block by his right hand, does he move the first block to his left hand and pick up the second block with his right hand?

30. If you put cheerios or $M \& M^{\prime} s$ in front of him, does he pick up at least two of the cheerios or $M \& M^{\prime} s$ using his whole hand? 
Instructions: Please answer each question to the best of your ability. Do not try these with your child, simply try to remember what you have seen and score each according to the $0,1,2$. Some will be too easy for your child and some are beyond your child's abilities at this time. We want to see if what we see at school is what you see at home.

\section{0: My child cannot do this at this time \\ 1: I think my child can do this or I haven't seen my child do this at this time \\ 2: My child can do this at this time \\ SECTION 4}

31. Do you believe that your child could remove a peg from a pegboard?

32. Does he pick up a block using his thumb and first 2 fingers (pointer and middle)?

33. When he is holding a block with his left hand and you place a second block close to his right hand, does he pick up the second block with his right hand and bring the 2 blocks together?

34. When he is holding two blocks, does he continue to hold them when picking up a third block?

35. When you put a cheerio or $M \& M$ in front of him, does he pick up one up using his thumb and first 2 fingers (pointer and middle)?

36. When you put a cheerio or $M \& M$ in front of him, does he pick up one up by using the inside of his thumb and the inside of his pointer finger?

37. When you place a piece of paper in front of him, does he wrinkle the paper with his hands?

38. Does your child clap his hands together? 
Instructions: Please answer each question to the best of your ability. Do not try these with your child, simply try to remember what you have seen and score each according to the $0,1,2$. Some will be too easy for your child and some are beyond your child's abilities at this time. We want to see if what we see at school is what you see at home.

0: My child cannot do this at this time

1: I think my child can do this or I haven't seen my child do this at this time

2: My child is able to do this at this time

\section{SECTION 5}

39. Does he remove 2 rings from a ring stand? $\begin{array}{lllll}0 & 1 & 2\end{array}$

40. Does he poke with his pointer finger? $\quad \begin{array}{llll}0 & 1 & 2\end{array}$

41. When you give your child a bottle with

cheerios or $M \& M^{\prime} s$ in it, does he try to

shake the bottle in a side to side motion? $\quad \begin{array}{lll}0 & 1 & 2\end{array}$

42. When you put cheerios or $M \& M^{\prime} s$ in front of him, does he pick them up using his thumb and tip of his pointer or middle finger and bring them to his mouth?

43. When he is holding a block or toy, does he give it to you when you ask for it or put your hand out?

44. Does he put 3 blocks into a cup or other container?

45. When he sees you stir in a cup, will he then stir in a cup?

46. When he sees you hit a cup with a spoon, will he then hit the cup with the spoon? 
Instructions: Please answer each question to the best of your ability. Do not try these with your child, simply try to remember what you have seen and score each according to the $0,1,2$. Some will be too easy for your child and some are beyond your child's abilities at this time. We want to see if what we see at school is what you see at home.

0: My child cannot do this at this time

1: I think my child can do this or I haven't seen my child do this at this time

2: My child can do this at this time

\section{SECTION 6}

47. Do you believe your child could pull out 3 pegs from a pegboard?

48. When you place like cheerios

or $M \& M^{\prime} s$ into a small box, does he open the box to get them out?

49. When you place $M \& M^{\prime}$ s or cheerios into a small bottle without a cap, does he get the candy or cheerios out by dumping?

50. Does your child turn pages of a cardboard book (can be more than 1 page at a time)?

51. Does he pick up a block using his thumb on one side of the block and his pointer and middle finger on the other side of the block?

52. Does he put 2 blocks on top of each other?

53. Does he pick up 2 blocks at one time with one hand?

54. When your child is given a puzzle of 3 shapes (circle, triangle, and square), does he place one shape into the puzzle? 
Instructions: Please answer each question to the best of your ability. Do not try these with your child, simply try to remember what you have seen and score each according to the $0,1,2$. Some will be too easy for your child and some are beyond your child's abilities at this time. We want to see if what we see at school is what you see at home.

0: My child cannot do this at this time

1: I think my child can do this or I haven't see my child do this at this time

2: My child is able to do this at this time

\section{SECTION 7}

55. When you wrap a toy or block loosely with

a tissue, does he try to find it by unwrapping it?

56. If your child was given 7 blocks to put into a cup, could he put all the blocks into the cup?

57. Does he put 3 or 4 blocks on top of each other?

58. Does he scribble on a piece of paper after watching you scribble?

59. When he holds a crayon, does he hold the crayon with his thumb and first finger pointed downward while the other 3 fingers are around the crayon (like holding a spoon).

60. Does he put 3 pegs into a pegboard?

61. Does he take off his socks without your help?

62. When he is given a circle, triangle, and square, does he put 2 of the shapes into the puzzle without your help? 
Instructions: Please answer each question to the best of your ability. Do not try these with your child, simply try to remember what you have seen and score each according to the $0,1,2$. Some will be too easy for your child and some are beyond your child's abilities at this time. We want to see if what we see at school is what you see at home.

0: My child cannot do this at this time

1: I think my child can do this or I haven't seen my child do this at this time

2: My child can do this at this time

\section{SECTION 8}

63. When you give your child $M \& M^{\prime} s$ or cheerios and a small bottle, does he put at least

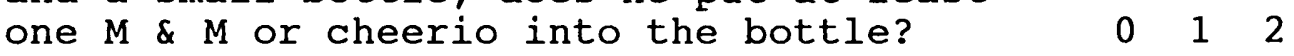

64. Does he pull apart pop beads in one place?

65. Does he turn thick pages of a book 1 or 2 at a time?

66. When you give your child a puzzle with 3 shapes (circle, triangle, square), does he put all the shapes back into the right place?

67. Does he put 6 to 8 blocks on top of each other?

68. If you draw up and down lines on a piece of paper, does he make up and down lines?

69. Does your child string 3 beads after you show him how to do it?

70. Does he cut the paper in one place when you show him how to cut with scissors? 
Instructions: Please answer each question to the best of your ability. Do not try these with your child, simply try to remember what you have seen and score each according to the $0,1,2$. Some will be too easy for your child and some are beyond your child's abilities at this time. We want to see if what we see at school is what you see at home.

0: My child cannot do this at this time

1: I think my child can do this or I haven't seen my child do this at this time

2: My child can do this at this time

\section{SECTION 9}

71. Does your child open the door by turning the knob?

72. When you give him 5 rings and a ring stand, does your child place all 5 rings $\begin{array}{llll}\text { on the stand? (The order does not matter) } & 0 & 1 & 2\end{array}$

73. When you give him a small bottle with $M \& M^{\prime} s$ and place a cap on it, does he remove the cap to get to the candy?

74. Does he pull apart 4 pop beads?

75. When you draw a line going side to side, does he make one like yours?

76. When you make a train with blocks ( 3 blocks together and 1 on top) does he make a one like yours? 
Instructions: Please answer each question to the best of your ability. Do not try these with your child, simply try to remember what you have seen and score each according to the $0,1,2$. Some will be too easy for your child and some are beyond your child's abilities at this time. We want to see if what we see at school is what you see at home.

0: My child cannot do this at this time

1: I think my child can do this or I haven't seen my child do this at this time

2: My child can do this at this time

\section{SECTION 10}

77. Does your child put 9 or 10 blocks on top of each other?

78. When you build a bridge with blocks

( 2 blocks next to each other with a

little space and 1 block on top), does he build one like yours?

79. When you show him a picture of a circle, does he draw a circle with the beginning and ending point close together?

80. Does he wash his hands so that the top and bottom side are being cleaned?

$\begin{array}{lll}0 & 1 & 2\end{array}$

81. Does he unbutton large buttons?

$\begin{array}{lll}0 & 1 & 2\end{array}$

82. Does he cut a small piece in half, after you show him how?

$\begin{array}{lll}0 & 1 & 2\end{array}$ 
Instructions: Please answer each question to the best of your ability. Do not try these with your child, simply try to remember what you have seen and score each according to the $0,1,2$. Some will be too easy for your child and some are beyond your child's abilities at this time. We want to see if what we see at school is what you see at home.

0: My child cannot do this at this time

1: I think my child can do this or I haven't seen my child do this at this time

2: My child is able to do this at this time

\section{SECTION 11}

83. Does your child use one hand more than another?

84. Does he remove a cap from a bottle in a short amount of time?

85. Does he string 5 or more beads?

86. When you wind up a wind-up toy and give it to him, does he wind up the toy after it stops?

87. Does he cut with scissors on a line?

88. When you show him a picture of 2 lines crossing each other (a cross), does he draw one like it? 
Instructions: Please answer each question to the best of your ability. Do not try these with your child, simply try to remember what you have seen and score each according to the $0,1,2$. Some will be too easy for your child and some are beyond your child's abilities at this time. We want to see if what we see at school is what you see at home.

0: My child cannot do this at this time

1: I think my child can do this or I haven't seen my child do this at this time

2: My child can do this at this time

\section{SECTION 1}

1. When you place your finger in your

child's hand, does she close her hand? $\quad \begin{array}{llll}0 & 1 & 2\end{array}$

2. Does your child keep her hands closed

for 10 seconds?

$\begin{array}{lll}0 & 1 & 2\end{array}$

3. Does your child look at toys for 5 seconds?

4. When you slowly move a rattle in front of your child to one side, does she follow the rattle with her eyes? $\quad \begin{array}{lllll}0 & 1 & 2\end{array}$

5. When your child's head is turned to the side, can she follow a rattle back to the front(middle) with her eyes?

6. When you place a rattle in your child's hand, does she drop the rattle within 3 seconds?

7. When your child is on her back with her head turned to the side, does she follow a rattle past the to the other side?

8. When you place a rattle in your child's hand, does your child hold on to the rattle and move it?

9. When a rattle touches on the inside of your child's hand, does she close her hand onto the rattle and hold it? 
Instructions: Please answer each question to the best of your ability. Do not try these with your child, simply try to remember what you have seen and score each according to the $0,1,2$. Some will be too easy for your child and some are beyond your child's abilities at this time. We want to see if what we see at school is what you see at home.

0: My child cannot do this at this time

1: I think my child can do this or I haven't seen my child do this at this time

2: My child can do this at this time

\section{SECTION 1}

10. Does your child hold on to toys/rattle for at least 30 seconds?

11. When your child is on her back, does she reach for a rattle?

12. When your child is on her back, does she move his head to avoid something coming towards her face?

13. When something rolls past your child, does she follow it with her eyes?

14. Does your child look at her hands? 
Instructions: Please answer each question to the best of your ability. Do not try these with your child, simply try to remember what you have seen and score each according to the $0,1,2$. Some will be too easy for your child and some are beyond your child's abilities at this time. We want to see if what we see at school is what you see at home.

0: My child cannot do this at this time

1: I think my child can do this or I haven't seen my child do this at this time

2: My child can do this at this time

\section{SECTION 2}

15. When you wave a rattle or toy in front of your child, does she move her arms and hands?

16. When you place a rattle in her hand, does your child hold and move the rattle for at least one minute?

17. Does your child reach and hold on to a rattle while sitting in your lap?

18. When you dangle a toy in front of her, does she move her hand towards the toy?

19. When she is lying on her tummy, does she reach and pull a toy towards her?

20. Does she try to pick up paper by wrinkling it?

21. When you place a block close to her hand, does she reach and grab the block using the inside of her hand?

22. When you place a block in her hand, does she bring her hands together? 
Instructions: Please answer each question to the best of your ability. Do not try these with your child, simply try to remember what you have seen and score each according to the $0,1,2$. Some will be too easy for your child and some are beyond your child's abilities at this time. We want to see if what we see at school is what you see at home.

\section{0: My child cannot do this at this time \\ 1: I think my child can do this or I haven't seen my child do this at this time \\ 2: My child can do this at this time}

\section{SECTION 3}

23. When you bang a cup on your child's high chair, does she try to pick up the cup by it's handle and lift it up?

24. Does your child bang a cup on a table? $\begin{array}{lll}0 & 1 & 2\end{array}$

25. Does your child pick up the rattle using the inside of her hand near the thumb and first 2 fingers (pointer and middle)? $\quad \begin{array}{llll}0 & 1 & 2\end{array}$

26. Does she shake a rattle?

27. When your child picks up a block, does she use the inside of her hand close to the wrist and the last 2 fingers (ring and pinkie) to hold the block.

28. While she is holding on to one block, does she pick up a second block without dropping the first one?

29. When she is holding a block in her right hand and you place a second block by her right hand, does she move the first block to her left hand and pick up the second block with her right hand?

30. If you put cheerios or $M \& M^{\prime} s$ in front of her, does she pick up at least two of the cheerios or $M \& M^{\prime} s$ using her whole hand? 
Instructions: Please answer each question to the best of your ability. Do not try these with your child, simply try to remember what you have seen and score each according to the $0,1,2$. Some will be too easy for your child and some are beyond your child's abilities at this time. We want to see if what we see at school is what you see at home.

0: My child cannot do this at this time

1: I think my child can do this or I haven't seen my child do this at this time

2: My child can do this at this time

\section{SECTION 4}

31. Do you believe that your child could

remove a peg from a pegboard?

$\begin{array}{lll}0 & 1 & 2\end{array}$

32. Does she pick up a block using

her thumb and first 2 fingers

(pointer and middle)?

$\begin{array}{lll}0 & 1 & 2\end{array}$

33. When she is holding a block with

her left hand and you place a second

block close to her right hand, does

she pick up the second block with her

right hand and bring the 2 blocks

together?

$\begin{array}{lll}0 & 1 & 2\end{array}$

34. When she is holding two blocks, does she continue to hold them when picking up

a third block?

$\begin{array}{lll}0 & 1 & 2\end{array}$

35. When you put a cheerio or $M \& M$ in front of her, does she pick up one up using her thumb and first 2 fingers (pointer and middle)?

36. When you put a cheerio or $M \& M$ in front of her, does she pick up one up by using the inside of her thumb and the inside of her pointer finger?

37. When you place a piece of paper in front of her, does she wrinkle the paper with her hands? 
Instructions: Please answer each question to the best of your ability. Do not try these with your child, simply try to remember what you have seen and score each according to the $0,1,2$. Some will be too easy for your child and some are beyond your child's abilities at this time. We want to see if what we see at school is what you see at home.

\section{0: My child cannot do this at this time \\ 1: I think my child can do this or I haven't seen my child do this at this time \\ 2: My child is able to do this at this time \\ SECTION 5}

38. Does your child clap her hands together?

$\begin{array}{lll}0 & 1 & 2\end{array}$

39. Does she remove 2 rings from a ring stand? $0 \begin{array}{lll}0 & 1 & 2\end{array}$

40. Does she poke with her pointer finger? $\quad 0 \begin{array}{lll}0 & 1\end{array}$

41. When you give your child a bottle with cheerios or $M \& M^{\prime} s$ in it, does she try to shake the bottle in a side to side motion? $\begin{array}{llll}0 & 1 & 2\end{array}$

42. When you put cheerios or $M \& M^{\prime}$ s in front of her, does she pick them up using her thumb and tip of his pointer or middle finger and bring them to her mouth?

43. When she is holding a block or toy, does she give it to you when you ask for it or put your hand out?

44. Does she put 3 blocks into a cup or other container?

45. When she sees you stir in a cup, will she then stir in a cup?

46. When she sees you hit a cup with a spoon, will she then hit the cup with the spoon? 
Instructions: Please answer each question to the best of your ability. Do not try these with your child, simply try to remember what you have seen and score each according to the $0,1,2$. Some will be too easy for your child and some are beyond your child's abilities at this time. We want to see if what we see at school is what you see at home.

0: My child cannot do this at this time

1: I think my child can do this or I haven't seen my child do this at this time

2: My child can do this at this time

\section{SECTION 6}

47. Do you believe your child could pull out 3 pegs from a pegboard?

48. When you place like cheerios or $M \& M^{\prime} s$ into a small box, does she open the box to get them out?

49. When you place $M \& M^{\prime}$ s or cheerios into a small bottle without a cap, does she get the candy or cheerios out by dumping?

50. Does your child turn pages of a cardboard book (can be more than 1 page at a time)?

51. Does she pick up a block using her thumb on one side of the block and her pointer and middle finger on the other side of the block?

52. Does she put 2 blocks on top of each other?

53. Does she pick up 2 blocks at one time with one hand?

54. When your child is given a puzzle of 3 shapes (circle, triangle, and square), does she place one shape into the puzzle? 
Instructions: Please answer each question to the best of your ability. Do not try these with your child, simply try to remember what you have seen and score each according to the $0,1,2$. Some will be too easy for your child and some are beyond your child's abilities at this time. We want to see if what we see at school is what you see at home.

0: My child cannot do this at this time 1: I think my child can do this or I haven't seen my child do this at this time

2: My child is able to do this at this time

\section{SECTION 7}

55. When you wrap a toy or block loosely with

a tissue, does she try to find it by unwrapping it?

56. If your child was given 7 blocks to put into a cup, could she put all the blocks into the cup?

57. Does she put 3 or 4 blocks on top of each other?

58. Does she scribble on a piece of paper after watching you scribble?

59. When she holds a crayon, does she hold the crayon with her thumb and first finger pointed downward while the other 3 fingers are around the crayon (like holding a spoon).

60. Does she put 3 pegs into a pegboard?

61. Does she take off his socks without your help?

62. When she is given a circle, triangle, and square, does she put 2 of the shapes into the puzzle without your help? 
Instructions: Please answer each question to the best of your ability. Do not try these with your child, simply try to remember what you have seen and score each according to the $0,1,2$. Some will be too easy for your child and some are beyond your child's abilities at this time. We want to see if what we see at school is what you see at home.

0: My child cannot do this at this time

1: I think my child can do this or I haven't seen my child do this at this time

2: My child can do this at this time

\section{SECTION 8}

63. When you give your child $M \& M^{\prime}$ s or cheerios and a small bottle, does she put at least

one $M \& M$ or cheerio into the bottle?

64. Does she pull apart pop beads in one place?

65. Does she turn thick pages of a book 1 or 2 at a time?

66. When you give your child a puzzle with 3 shapes (circle, triangle, square), does she put all the shapes back into the right place?

67. Does she put 6 to 8 blocks on top of each other?

68. If you draw up and down lines on a piece of paper, does she make up and down lines?

69. Does your child string 3 beads after you show her how to do it?

70. Does she cut the paper in one place when you show her how to cut with scissors? 
Instructions: Please answer each question to the best of your ability. Do not try these with your child, simply try to remember what you have seen and score each according to the $0,1,2$. Some will be too easy for your child and some are beyond your child's abilities at this time. We want to see if what we see at school is what you see at home.

0: My child cannot do this at this time

1: I think my child can do this or I haven't seen my child do this at this time

2: My child can do this at this time

\section{SECTION 9}

71. Does your child open the door by turning the knob?

72. When you give her 5 rings and a ring stand, does your child place all 5 rings on the stand? (The order does not matter) $\begin{array}{llll}0 & 1 & 2\end{array}$

73. When you give her a small bottle with $M \& M^{\prime} s$ and place a cap on it, does she remove the cap to get to the candy?

74. Does she pull apart 4 pop beads?

75. When you draw a line going side to side, does she make one like yours?

76. When you make a train with blocks ( 3 blocks together and 1 on top) does she make a one like yours? 
Instructions: Please answer each question to the best of your ability. Do not try these with your child, simply try to remember what you have seen and score each according to the $0,1,2$. Some will be too easy for your child and some are beyond your child's abilities at this time. We want to see if what we see at school is what you see at home.

0: My child cannot do this at this time 1: I think my child can do this or I haven't seen my child do this at this time

2: My child can do this at this time

\section{SECTION 10}

77. Does your child put 9 or 10 blocks on top of each other?

78. When you build a bridge with blocks

( 2 blocks next to each other with a

little space and 1 block on top), does she build one like yours?

$\begin{array}{lll}0 & 1 & 2\end{array}$

79. When you show her a picture of a circle, does she draw a circle with the beginning and ending point close together?

80. Does she wash her hands so that the top and bottom side are being cleaned?

$\begin{array}{lll}0 & 1 & 2\end{array}$

81. Does she unbutton large buttons?

$\begin{array}{lll}0 & 1 & 2\end{array}$

82. Does she cut a small piece in half, after you show her how? 
Instructions: Please answer each question to the best of your ability. Do not try these with your child, simply try to remember what you have seen and score each according to the $0,1,2$. Some will be too easy for your child and some are beyond your child's abilities at this time. We want to see if what we see at school is what you see at home.

0: My child cannot do this at this time

1: I think my child can do this or I haven't seen my child do this at this time

2: My child is able to do this at this time

SECTION 11

83. Does your child use one hand more than another?

84. Does she remove a cap from a bottle in a short amount of time?

85. Does she string 5 or more beads?

86. When you wind up a wind-up toy and give it to her, does she wind up the toy after it stops?

87. Does she cut with scissors on a line?

88. When you show her a picture of 2 lines crossing each other( a cross), does she draw one like it? 
Instrucciones: Por favor, conteste cada pregunta con su mejor abilidad. No haga el intento de hacerlo con su hijo. Simplemente trate de recordar lo que ud. vió y dele el puntaje correspondiente de 0,1 y 2. Algunas preguntas van a ser muy fáciles y otras más dificiles de los que su hijo puede hacer en este momento. Nosotros queremos ver si lo que vemos acá en el colegio es lo mismo que ud. ve en la casa.

0: Mi hijo no lo puede hacer en este momento. 1: Creo que mi hijo lo puede hacer o yo no lo he visto hacer esto en este momento.

2: Mi hijo si puede hacer esto en este momento.

\section{SECCION 1}

1.- Cuando ud. apoya su dedo en la mano de su hijo, el la cierra?

$\begin{array}{lll}0 & 1 & 2\end{array}$

2.- Su hijo mantiene las manos cerradas por más de 10 segundos?

$\begin{array}{lll}0 & 1 & 2\end{array}$

3.- Su hijo puede mirar un juguete por 5 segundos?

4.- Cuando ud. mueve lentamente un maraca/sonajero en frente de su hijo hacia un lado, su hijo lo sigue?

$\begin{array}{lll}0 & 1 & 2\end{array}$

5.- Cuando la cabeza de su hijo está hacia un lado, puede el seguir con sus ojos el maraca hasta el frente (medio)?

$\begin{array}{lll}0 & 1 & 2\end{array}$

6.- Cuando ud. le pone un maraca en la mano de su hijo, el lo suelta en 3 segundos?

$\begin{array}{lll}0 & 1 & 2\end{array}$

7.- Cuando su hijo está acostado boca arriba con su cabeza hacia un costado, el lo sigue hasta el otro costado?

$\begin{array}{lll}0 & 1 & 2\end{array}$

8.- Cuando ud. le pone un maraca en la mano, su hijo lo sostiene y lo mueve?

$\begin{array}{lll}0 & 1 & 2\end{array}$

9. - Cuando el maraca toca la palma de la mano de su hijo, el cierra la mano y lo sostiene?

10. - Su hijo sostiene un maraca por lo menos 30 segundos? 
Instrucciones: Por favor, conteste cada pregunta con su mejor abilidad. No haga el intento de hacerlo con su hijo. Simplemente trate de recordar lo que ud. vió y dele el puntaje correspondiente de 0,1 y 2 . Algunas preguntas van a ser muy fáciles y otras más dificiles de los que su hijo puede hacer en este momento. Nosotros queremos ver si lo que vemos acá en el colegio es lo mismo que ud. ve en la casa.

0: Mi hijo no lo puede hacer en este momento. 1: Creo que mi hijo lo puede hacer o yo no lo he visto hacer esto en este momento.

2: Mi hijo si puede hacer esto en este momento.

\section{SECCION 1}

11. - Cuando su hijo esta acostado boca arriba, el agarra una maraca?

12. - Cuando su hijo esta acostado boca arriba, si algo se le acerca hacia la cara, el trata de esquivarlo moviendo su cabeza?

13.- Cuando algo rueda al frente de su hijo, el lo sigue con los vista?

14.- Su hijo se mira las manos?

$\begin{array}{lll}0 & 1 & 2\end{array}$


Instrucciones: Por favor, conteste cada pregunta con su mejor abilidad. No haga el intento de hacerlo con su hijo. Simplemente trate de recordar lo que ud. vió y dele el puntaje correspondiente de $0,1 \mathrm{y} 2$. Algunas preguntas van a ser muy fáciles y otras más dificiles de los que su hijo puede hacer en este momento. Nosotros queremos ver si lo que vemos acá en el colegio es lo mismo que ud. ve en la casa.

0: Mi hijo no lo puede hacer en este momento.

1: Creo que mi hijo lo puede hacer o yo no lo he visto hacer esto en este momento.

2: Mi hijo si puede hacer esto en este momento.

\section{SECCION 2}

15. - Cuando ud. mueve una maraca en frente de su hijo, el mueve sus brazos y manos?

16. - Cuando ud. pone un maraca en la mano de su hijo el lo agarra y lo mueve por lo menos por un minuto?

17.- Cuando su hijo esta sentado sobre sus pierna, el trata de agarrar y sostener el sonajero?

18.- Cuando ud. cuelga un juguete en frente de su hijo el mueve sus manos hacia el juguete?

19. - Cuando esta acostado boca abajo, el alcanza y hala del juguete hacia el para obtenerlo? $0 \begin{array}{lll}2 & 1\end{array}$

20. - Su hijo trata de agarrar un papel y arrugarlo?

21.- Cuando ud. coloca un bloque en frente del nino, el estira los brazos para agarrarlo usando la palma de la mano?

22.- Cuando ud. coloca un bloque en la mano de su hijo, el lleva las dos manos juntas? $\begin{array}{llll}0 & 1 & 2\end{array}$ 
Instrucciones: Por favor, conteste cada pregunta con su mejor abilidad. No haga el intento de hacerlo con su hijo. Simplemente trate de recordar lo que ud. vió y dele el puntaje correspondiente de 0,1 y 2. Algunas preguntas van a ser muy fáciles y otras más dificiles de los que su hijo puede hacer en este momento. Nosotros queremos ver si lo que vemos acá en el colegio es lo mismo que ud. ve en la casa.

0: Mi hijo no lo puede hacer en este momento.

1: Creo que mi hijo lo puede hacer o yo no lo he visto hacer esto en este momento.

2: Mi hijo si puede hacer esto en este momento.

\section{SECCION 3}

23. - Si ud. golpea con una taza la silla de comer de su hijo, el trata de agarrar la taza por las manijas (asas) y levantarla?

24.- Su hijo golpea la taza en la mesa?

25. - Su hijo es capaz de levantar un maraca usando la palma de la mano con el indice y el dedo mediano?

26. - Su hijo puede hacer sonar la maraca?

27. - Cuando su hijo coje un bloque, el lo hace con palma de la mano y cerca de los dedos anular y menique?

28. - Cuando su hijo tiene un bloque en la mano, puede el recoger un segundo bloque sin soltar el primero?

29. - Cuando su hijo tiene un bloque con la mano derecha y ud. le da otro para que lo tome con la misma mano, el pasa el cubo a la mano izquierda $y$ toma el que le ofrece con la derecha?

30. - Si ud. pone cheerios o $M \& M^{\prime} s$ en frente de su hijo el agarra por lo menos dos de ellos usando toda la mano? 
Instrucciones: Por favor, conteste cada pregunta con su mejor abilidad. No haga el intento de hacerlo con su hijo. Simplemente trate de recordar lo que ud. vió y dele el puntaje correspondiente de 0,1 y 2. Algunas preguntas van a ser muy fáciles y otras más dificiles de los que su hijo puede hacer en este momento. Nosotros queremos ver si lo que vemos acá en el colegio es lo mismo que ud. ve en la casa.

\section{0: Mi hijo no lo puede hacer en este momento.} 1: Creo que mi hijo lo puede hacer o yo no lo he visto hacer esto en este momento.

2: Mi hijo si puede hacer esto en este momento.

\section{SECCION 4}

31.- Cree ud. que su hijo puede sacar una clavija del tablero que los contiene?

32.- Su hijo puede agarrar un bloque usando el dedo pulgar y los dos primeros dedos (indice $y$ medio)?

33.- Si el tiene un cubo en la mano izquierda $y$ ud. le da un segundo cubo para que lo tome con la mano derecha. Puede su hijo tomar el segundo cubo con la mano derecha $y$ poner los dos cubos juntos en el medio?

34.- Si su hijo tiene dos bloques en las manos, puede el tenerlos y a la misma vez tomar un tercero?

35.- Si ud. pone cheerios $\circ \mathrm{M} \& M^{\prime}$ s en frente de su hijo puede el tomar uno con los dedos pulgar, indice $y$ medio a la vez?

36.- Si ud. pone cheerios $\circ \mathrm{M} \& M^{\prime}$ s en frente de su hijo, puede el tomarlo con la punta de los dedos pulgar e indice?

37.- Si su hijo tiene un papel en frente, puede el tomarlo y arrugarlo con las dos manos?

38.- Puede su hijo aplaudir ?

$\begin{array}{lll}0 & 1 & 2 \\ 0 & 1 & 2\end{array}$


Instrucciones: Por favor, conteste cada pregunta con su mejor abilidad. No haga el intento de hacerlo con su hijo. Simplemente trate de recordar lo que ud. vió y dele el puntaje correspondiente de 0,1 y 2. Algunas preguntas van a ser muy fáciles y otras más dificiles de los que su hijo puede hacer en este momento. Nosotros queremos ver si lo que vemos acá en el colegio es lo mismo que ud. ve en la casa.

0: Mi hijo no lo puede hacer en este momento.

1: Creo que mi hijo lo puede hacer o yo no 10 he visto hacer esto en este momento.

2: Mi hijo si puede hacer esto en este momento.

\section{SECCION 5}

39. - Puede su hijo sacar dos anillos/aros del estante que los sostiene?

40.- Puede su hijo empujar con el dedo indice?

$\begin{array}{lll}0 & 1 & 2\end{array}$

41.- Si ud. le da a su hijo una botella con una bolita adentro, trata el de batir la botella hacia un lado $y$ al otro?

42.- Si ud. coloca cheerios o $M \& M^{\prime}$ s en frente de su hijo, trata el de tomarlos con el dedo pulgar y la punta del dedo indice $y$ se lo lleva a la boca?

43.- Si el tiene un bloque o un juguete en la mano intenta su hijo darselo si ud. se lo pide o si le pone su mano en frente? $\begin{array}{lllll}0 & 1 & 2\end{array}$

44.- Puede su hijo poner tres bloques dentro de una taza o cualquier otro recipiente?

45.- Si su hijo lo ve revolviendo algo en una taza, intenta el hacer lo mismo?

46. - Si su hijo lo ve golpeando una taza con una cuchara, intenta el hacer lo mismo? 
Instrucciones: Por favor, conteste cada pregunta con su mejor abilidad. No haga el intento de hacerlo con su hijo. Simplemente trate de recordar lo que ud. vió y dele el puntaje correspondiente de 0,1 y 2. Algunas preguntas van a ser muy fáciles y otras más dificiles de los que su hijo puede hacer en este momento. Nosotros queremos ver si lo que vemos acá en el colegio es lo mismo que ud. ve en la casa.

0: Mi hijo no lo puede hacer en este momento.

1: Creo que mi hijo lo puede hacer o yo no lo he visto hacer esto en este momento.

2: Mi hijo si puede hacer esto en este momento.

\section{SECCION 6}

47.- Cree ud. que su hijo puede sacar tres clavijas de un tablero que los contiene?

48.- Si ud. coloca cheerios o M\&M's dentro de una caja puede su hijo abrirla para sacarlos?

49. - Si ud. coloca cheerios o M\&M's dentro de una botella, su hijo intenta sacarlos de la botella?

50.- Puede su hijo pasar las paginas de un libro de figuras (puede ser mas de una pagina a la vez)?

51.- Puede su hijo agarrar un bloque con el pulgar de un lado y el indice $y$ el medio del otro lado del bloque?

52.- Puede su hijo poner un bloque arriba del otro?

53.- Puede su hijo agarrar dos bloques con la misma mano al mismo tiempo?

54.- Si ud. le da un rompecabezas de 3 piezas con tres formas distintas (circulo, triangulo y cuadrado), puede su hijo poner una pieza en el rompecabezas? 
Instrucciones: Por favor, conteste cada pregunta con su mejor abilidad. No haga el intento de hacerlo con su hijo. Simplemente trate de recordar lo que ud. vió y dele el puntaje correspondiente de 0,1 y 2. Algunas preguntas van a ser muy fáciles y otras más dificiles de los que su hijo puede hacer en este momento. Nosotros queremos ver si lo que vemos acá en el colegio es lo mismo que ud. ve en la casa.

0: Mi hijo no lo puede hacer en este momento. 1: Creo que mi hijo lo puede hacer o yo no lo he visto hacer esto en este momento.

2: Mi hijo si puede hacer esto en este momento.

\section{SECCION 7}

55. - Si ud. envuelve con papel un juguete o bloque y lo esconde, intenta su hijo encontrarlo removiendo la cobertura?

56.- Si ud. le da 7 bloques a su hijo, intentaria el ponerlos todos dentro de una taza?

57.- Puede su hijo poner $3 \circ 4$ bloques uno arriba del otro?

58.- Hace su hijo garabatos en un papel despues que ud. lo hizo?

59.- Cuando su hijo agarra un crayon, lo hace el con el pulgar y el indice mientras que los otros tres dedos envuelven el crayon, y con la punta del mismo hacia abajo? (como si sostuviera una cuchara)

60.- Puede su hijo poner tres palitos de madera o clavijas en el tablero que los contiene?

61.- Puede su hijo quitarse las medias sin ayuda?

62. - Si ud. le da un circulo, un triangulo y un cuadrado puede su hijo poner dos figuras en el rompecabezas sin su ayuda? 
Instrucciones: Por favor, conteste cada pregunta con su mejor abilidad. No haga el intento de hacerlo con su hijo. Simplemente trate de recordar lo que ud. vió y dele el puntaje correspondiente de 0,1 y 2. Algunas preguntas van a ser muy fáciles y otras más dificiles de los que su hijo puede hacer en este momento. Nosotros queremos ver si lo que vemos acá en el colegio es lo mismo que ud. ve en la casa.

0: Mi hijo no lo puede hacer en este momento. 1: Creo que mi hijo lo puede hacer o yo no lo he visto hacer esto en este momento.

2: Mi hijo si puede hacer esto en este momento.

\section{SECCION 8}

63. - Si ud. le da cheerios o M\&M's y una botella pequena, puede su hijo poner por lo menos un M\&M o un cheerio dentro de ella?

64. - Puede el separar bolitas o cuentas halando de un solo lado?

65.- Puede su hijo pasar las paginas de un libro grueso de una o dos a la vez?

66. - Si ud. le da un rompecabezas a su hijo con un circulo, un triangulo y un cuadrado, puede el poner todas las piezas en el lugar correcto?

67. - Puede el poner 6 a 8 bloques uno arriba del otro?

68. - Si ud. escribe en un papel lineas para arriba y para abajo, puede su hijo trazar las mismas lineas?

69. - Puede su hijo pasar tres bolitas por un agujero despues que ud. le muestra como hacerlo?

70. - Puede su hijo cortar un papel despues que ud. le muestra como hacerlo? 
Instrucciones: Por favor, conteste cada pregunta con su mejor abilidad. No haga el intento de hacerlo con su hijo. Simplemente trate de recordar lo que ud. vió y dele el puntaje correspondiente de $0,1 \mathrm{y} 2$. Algunas preguntas van a ser muy fáciles y otras más dificiles de los que su hijo puede hacer en este momento. Nosotros queremos ver si lo que vemos acá en el colegio es lo mismo que ud. ve en la casa.

0: Mi hijo no lo puede hacer en este momento.

1: Creo que mi hijo lo puede hacer o yo no lo he visto hacer esto en este momento.

2: Mi hijo si puede hacer esto en este momento.

\section{SECCION 9}

71. - Puede su hijo abrir la puerta dandole vuelta a la manija?

72.- Si ud. le da 5 anillos y un estante para sostenerlos, puede su hijo poner los 5 anillos en el estante? (El orden en que lo hace no interesa)

73. - Si ud. le da una botella con M\&M's adentro, y le pone tapa puede su hijo quitar la tapa para obtener los caramelos? $\begin{array}{llll}0 & 1 & 2\end{array}$

74.- Puede su hijo separar 4 cuentas plasticas? $\quad \begin{array}{llll}0 & 1 & 2\end{array}$

75. - Si ud. traza una linea de un lado al otro de la pagina, su hijo intenta copiar lo que ud. hizo?

76. - Si ud. hace un tren con bloques ( 3 bloques juntos y uno arriba de ellos), puede su hijo hacer uno igual? 
Instrucciones: Por favor, conteste cada pregunta con su mejor abilidad. No haga el intento de hacerlo con su hijo. Simplemente trate de recordar lo que ud. vió y dele el puntaje correspondiente de 0,1 y 2. Algunas preguntas van a ser muy fáciles y otras más dificiles de los que su hijo puede hacer en este momento. Nosotros queremos ver si lo que vemos acá en el colegio es lo mismo que ud. ve en la casa.

0: Mi hijo no lo puede hacer en este momento.

1: Creo que mi hijo lo puede hacer o yo no lo he visto hacer esto en este momento.

2: Mi hijo si puede hacer esto en este momento.

\section{SECCION 10}

77.- Puede su hijo poner 9 o 10 bloques uno arriba del otro?

78.- Si ud. contruye un puente poniendo dos bloques cerca uno del otro y un tercer bloque arriba de los dos anteriores, puede su hijo hacer uno como el suyo?

79.- Si ud. le muestra a su hijo una figura de un circulo, puede el dibujar uno como ese con las dos puntas del circulo cerca?

80. - Puede el lavarse las manos de manera tal que toda la palma como el dorso de las manos le queden limpias?

81. - Puede su hijo desabotonarse botones grandes?

82. - Puede el cortar un pedazo pequeno en dos mitades despues que ud. le muestra como hacerlo? 
Instrucciones: Por favor, conteste cada pregunta con su mejor abilidad. No haga el intento de hacerlo con su hijo. Simplemente trate de recordar lo que ud. vió y dele el puntaje correspondiente de 0,1 y 2. Algunas preguntas van a ser muy fáciles y otras más dificiles de los que su hijo puede hacer en este momento. Nosotros queremos ver si lo que vemos acá en el colegio es lo mismo que ud. ve en la casa.

0: Mi hijo no lo puede hacer en este momento. 1: Creo que mi hijo lo puede hacer o yo no lo he visto hacer esto en este momento.

2: Mi hijo si puede hacer esto en este momento.

SECCION 11

83. - Usa su hijo una mano mas que la otra?

$\begin{array}{lll}0 & 1 & 2\end{array}$

84.- Puede el quitarle la tapa a una botella en poco tiempo?

85.- Puede su hijo ensaltar 5 o mas bolitas en un hilo?

$\begin{array}{lll}0 & 1 & 2\end{array}$

86. - Cuando ud. le da cuerda a un juguete y se lo da a su hijo, puede su hijo darle cuerda al juguete cuando este termina de moverse?

87.- Puede su hijo cortar una linea con las tijeras?

88. - Puede su hijo dibujar dos lineas que se cruzan (en forma de una cruz) despues que ud. le muestra como hacerlo? 
Instrucciones: Por favor, conteste cada pregunta con su mejor abilidad. No haga el intento de hacerlo con su hija. Simplemente trate de recordar lo que ud. vió y dele el puntaje correspondiente de $0,1, y 2$. Algunas preguntas van a ser muy fáciles y otras más dificiles de los que su hija puede hacer en este momento. Nosotros queremos ver si lo que vemos acá en el colegio es lo mismo que ud. ve en la casa.

0: Mi hija no lo puede hacer en este momento. 1: Creo que mi hija lo puede hacer o yo no lo he visto hacer esto en este momento.

2: Mi hija si puede hacer esto en este momento.

SECCION 1

1.- Cuando ud. apoya su dedo en la mano de su hija, ella la cierra?

2.- Su hija mantiene las manos cerradas por más de 10 segundos?

3.- Su hija puede mirar un juguete por 5 segundos?

4.- Cuando ud. mueve lentamente un maraca/sonajero en frente de su hija hacia un lado, su hija lo sigue?

5.- Cuando la cabeza de su hija está hacia un lado, puede ella seguir con sus ojos ella maraca hasta ella frente (medio)?

6.- Cuando ud. le pone un maraca en la mano de su hija, ella lo suelta en 3 segundos? $\quad \begin{array}{lllll}0 & 1 & 2\end{array}$

7.- Cuando su hija está acostado boca arriba con su cabeza hacia un costado, ella lo sigue hasta ella otro costado?

8.- Cuando ud. le pone un maraca en la mano, su hija lo sostiene y lo mueve?

9.- Cuando ella maraca toca la palma de la mano de su hija, ella cierra la mano y lo sostiene?

10. - Su hija sostiene un maraca por lo menos 30 segundos? 
Instrucciones: Por favor, conteste cada pregunta con su mejor abilidad. No haga el intento de hacerlo con su hija. Simplemente trate de recordar lo que ud. vió y dele el puntaje correspondiente de 0,1 y 2. Algunas preguntas van a ser muy fáciles y otras más dificiles de los que su hija puede hacer en este momento. Nosotros queremos ver si lo que vemos acá en el colegio es lo mismo que ud. ve en la casa.

0: Mi hija no lo puede hacer en este momento. 1: Creo que mi hija lo puede hacer o yo no lo he visto hacer esto en este momento.

2: Mi hija si puede hacer esto en este momento.

\section{SECCION 1}

11. - Cuando su hija esta acostado boca arriba, ella agarra un maraca?

12. - Cuando su hija esta acostado boca arriba, si algo se le acerca hacia la cara, ella trata de esquivarlo moviendo su cabeza?

13. - Cuando algo rueda al frente de su hija, ella lo sigue con los ojos?

14.- Su hija se mira las manos?

$\begin{array}{lll}0 & 1 & 2\end{array}$ 
Instrucciones: Por favor, conteste cada pregunta con su mejor abilidad. No haga el intento de hacerlo con su hija. Simplemente trate de recordar lo que ud. vió y dele ella puntaje correspondiente de 0,1 y 2. Algunas preguntas van a ser muy fáciles y otras más dificiles de los que su hija puede hacer en este momento. Nosotros queremos ver si lo que vemos acá en ella colegio es lo mismo que ud. ve en la casa.

0: Mi hija no lo puede hacer en este momento.

1: Creo que mi hija lo puede hacer o yo no lo he visto hacer esto en este momento.

2: Mi hija si puede hacer esto en este momento.

\section{SECCION 2}

15. - Cuando ud. mueve una maraca en frente de su hija, ella mueve sus brazos y manos?

16. - Cuando ud. pone un maraca en la mano de su hija ella lo agarra y lo mueve por lo menos por un minuto?

17.- Cuando su hija esta sentado sobre sus pierna, ella trata de agarrar y sostener ella maraca?

18.- Cuando ud. cuelga un juguete en frente de su hija ella mueve sus manos hacia ella juguete?

19. - Cuando esta acostado boca abajo, ella alcanza y hala del juguete hacia ella para obtenerlo?

20. - Su hija trata de agarrar un papel y arrugarlo?

21. - Cuando ud. coloca un bloque en frente del nino, ella estira los brazos para agarrarlo usando la palma de la mano?

22. - Cuando ud. coloca un bloque en la mano de su hija, ella lleva las dos manos juntas? 
Instrucciones: Por favor, conteste cada pregunta con su mejor abilidad. No haga el intento de hacerlo con su hija. Simplemente trate de recordar lo que ud. vió y dele el puntaje correspondiente de 0,1 y 2. Algunas preguntas van a ser muy fáciles y otras más dificiles de los que su hija puede hacer en este momento. Nosotros queremos ver si lo que vemos acá en el colegio es lo mismo que ud. ve en la casa.

0: Mi hija no lo puede hacer en este momento. 1: Creo que mi hija lo puede hacer o yo no lo he visto hacer esto en este momento.

2: Mi hija si puede hacer esto en este momento. SECCION 3

23. - Si ud. golpea con una taza la silla de comer de su hija, ella trata de agarrar la taza por las manijas (asas) y levantarla?

24. - Su hija golpea la taza en la mesa?

$\begin{array}{lll}0 & 1 & 2\end{array}$

$0 \quad 12$

25. - Su hija es capaz de levantar un maraca usando la palma de la mano con ella indice $y$ ella dedo mediano?

$\begin{array}{lll}0 & 1 & 2\end{array}$

26. - Su hija puede hacer sonar la maraca?

$\begin{array}{lll}0 & 1 & 2\end{array}$

27. - Cuando su hija coje un bloque, ella lo hace con palma de la mano y cerca de los dedos anular $y$ menique?

$\begin{array}{lll}0 & 1 & 2\end{array}$

28. - Cuando su hija tiene un bloque en la mano, puede ella recoger un segundo bloque sin soltar ella primero?

29. - Cuando su hija tiene un bloque con la mano derecha $y$ ud. le da otro para que lo tome con la misma mano, ella pasa ella cubo a la mano izquierda y toma ella que le ofrece con la derecha?

30.- Si ud. pone cheerios o M\&M's en frente de su hija ella agarra por lo menos dos de ellos usando toda la mano? 
Instrucciones: Por favor, conteste cada pregunta con su mejor abilidad. No haga el intento de hacerlo con su hija. Simplemente trate de recordar lo que ud. vió y dele el puntaje correspondiente de 0,1 y 2. Algunas preguntas van a ser muy fáciles y otras más dificiles de los que su hija puede hacer en este momento. Nosotros queremos ver si lo que vemos acá en el colegio es lo mismo que ud. ve en la casa.

0: Mi hija no lo puede hacer en este momento.

1: Creo que mi hija lo puede hacer o yo no lo he visto hacer esto en este momento.

2: Mi hija si puede hacer esto en este momento.

\section{SECCION 4}

31.- Cree ud. que su hija puede sacar una clavija del tablero que los contiene?

32.- Su hija puede agarrar un bloque usando ella dedo pulgar y los dos primeros dedos(indice y medio)?

33.- Si ella tiene un cubo en la mano izquierda y ud. le da un segundo cubo para que lo tome con la mano derecha. Puede su hija tomar ella segundo cubo con la mano derecha y poner los dos cubos juntos en ella medio?

34.- Si su hija tiene dos bloques en las manos, puede ella tenerlos y a la misma vez tomar un tercero?

35. - Si ud. pone cheerios o M\&M's en frente de su hija puede ella tomar uno con los dedos pulgar, indice y medio a la vez?

36.- Si ud. pone cheerios 0 M\&M's en frente de su hijo, puede ella tomarlo con la punta de los dedos pulgar e indice?

37.- Si su hija tiene un papel en frente, puede ella tomarlo y arrugarlo con las dos manos? 
Instrucciones: Por favor, conteste cada pregunta con su mejor abilidad. No haga el intento de hacerlo con su hija. Simplemente trate de recordar lo que ud. vió y dele el puntaje correspondiente de $0,1 \mathrm{y} 2$. Algunas preguntas van a ser muy fáciles y otras más dificiles de los que su hija puede hacer en este momento. Nosotros queremos ver si lo que vemos acá en el colegio es lo mismo que ud. ve en la casa.

0: Mi hija no lo puede hacer en este momento. 1: Creo que mi hija lo puede hacer o yo no lo he visto hacer esto en este momento.

2: Mi hija si puede hacer esto en este momento. SECCION 5

39.- Puede su hija sacar dos anillos/aros del estante que los sostiene?

40.- Puede su hija empujar con ella dedo indice?

41.- Si ud. le da a su hija una botella con una bolita adentro, trata ella de batir la botella hacia un lado y al otro?

42.- Si ud. coloca cheerios o M\&M's en frente de su hija, trata ella de tomarlos con ella dedo pulgar y la punta del dedo indice y se lo lleva a la boca?

43.- Si ella tiene un bloque o un juguete en la mano intenta su hija darselo si ud. se lo pide o si le pone su mano en frente?

44.- Puede su hija poner tres bloques dentro de una taza o cualquier otro recipiente?

45.- Si su hija lo ve revolviendo algo en una taza, intenta ella hacer lo mismo?

46.- Si su hija lo ve golpeando una taza con una cuchara, intenta ella hacer lo mismo? 
Instrucciones: Por favor, conteste cada pregunta con su mejor abilidad. No haga el intento de hacerlo con su hija. Simplemente trate de recordar lo que ud. vió y dele el puntaje correspondiente de 0,1 y 2. Algunas preguntas van a ser muy fáciles y otras más dificiles de los que su hija puede hacer en este momento. Nosotros queremos ver si lo que vemos acá en el colegio es lo mismo que ud. ve en la casa.

0: Mi hija no lo puede hacer en este momento.

1: Creo que mi hija lo puede hacer o yo no lo he visto hacer esto en este momento.

2: Mi hija si puede hacer esto en este momento.

\section{SECCION 6}

47. - Cree ud. que su hija puede sacar tres clavijas de un tablero que los contiene?

48.- Si ud. coloca cheerios o M\&M's dentro de una caja puede su hija abrirla para sacarlos?

49.- Si ud. coloca cheerios o M\&M's dentro de una botella, su hija intenta sacarlos de la botella?

50. - Puede su hija pasar las paginas de un libro de figuras (puede ser mas de una pagina a la vez)?

51. - Puede su hija agarrar un bloque con ella pulgar de un lado y ella indice y ella medio del otro lado del bloque?

52.- Puede su hija poner un bloque arriba del otro?

53. - Puede su hija agarrar dos bloques con la misma mano al mismo tiempo?

54.- Si ud. le da un rompecabezas de 3 piezas con tres formas distintas (circulo, triangulo y cuadrado), puede su hija poner una pieza en ella rompecabezas? 
Instrucciones: Por favor, conteste cada pregunta con su mejor abilidad. No haga el intento de hacerlo con su hija. Simplemente trate de recordar lo que ud. vió y dele el puntaje correspondiente de 0,1 y 2. Algunas preguntas van a ser muy fáciles y otras más dificiles de los que su hija puede hacer en este momento. Nosotros queremos ver si lo que vemos acá en el colegio es lo mismo que ud. ve en la casa.

0: Mi hija no lo puede hacer en este momento.

1: Creo que mi hija lo puede hacer o yo no lo he visto hacer esto en este momento.

2: Mi hija si puede hacer esto en este momento.

\section{SECCION 7}

55.- Si ud. envuelve con papel un juguete o bloque $y$ lo esconde intenta su hija encontrarlo removiendo la cobertura?

56.- Si ud. le da 7 bloques a su hija, intentaria ella ponerlos todos dentro de una taza?

57.- Puede su hija poner 3 o 4 bloques uno arriba del otro?

58. - Hace su hija garabatos en un papel despues que ud. lo hizo?

59. - Cuando su hija agarra un crayon, lo hace ella con ella pulgar y ella indice mientras que los otros tres dedos envuelven ella crayon, y con la punta del mismo hacia abajo? (como si sostuviera una cuchara)

60. - Puede su hija poner tres palitos de madera o clavijas en ella tablero que los contiene?

61.- Puede su hija quitarse las medias sin ayuda?

62.- Si ud. le da un circulo, un triangulo y un cuadrado puede su hija poner dos figuras en ella rompecabezas sin su ayuda? 
Instrucciones: Por favor, conteste cada pregunta con su mejor abilidad. No haga el intento de hacerlo con su hija. Simplemente trate de recordar lo que ud. vió y dele el puntaje correspondiente de 0,1 y 2 . Algunas preguntas van a ser muy fáciles y otras más dificiles de los que su hija puede hacer en este momento. Nosotros queremos ver si lo que vemos acá en el colegio es lo mismo que ud. ve en la casa.

0: Mi hija no lo puede hacer en este momento.

1: Creo que mi hija lo puede hacer o yo no lo he visto hacer esto en este momento.

2: Mi hija si puede hacer esto en este momento.

\section{SECCION 8}

63. - Si ud. le da cheerios o M\&M's y una botella pequena, puede su hija poner por lo menos un M\&M o un cheerio dentro de ella?

64. - Puede ella separar bolitas o cuentas halando de un solo lado?

65. - Puede su hija pasar las paginas de un libro grueso de una o dos a la vez?

66.- Si ud. le da un rompecabezas a su hija con un circulo, un triangulo y un cuadrado, puede ella poner todas las piezas en ella lugar correcto?

67. - Puede ella poner 6 o 8 bloques uno arriba del otro?

68. - Si ud. escribe en un papel lineas para arriba y para abajo, puede su hija trazar las mismas lineas?

69. - Puede su hija pasar tres bolitas por un agujero despues que ud. le muestro como hacerlo?

70.- Puede su hija cortar un papel despues que ud. le muestro como hacerlo? 
Instrucciones: Por favor, conteste cada pregunta con su mejor abilidad. No haga el intento de hacerlo con su hija. Simplemente trate de recordar lo que ud. vió y dele el puntaje correspondiente de $0,1 \mathrm{y} 2$. Algunas preguntas van a ser muy fáciles y otras más dificiles de los que su hija puede hacer en este momento. Nosotros queremos ver si lo que vemos acá en el colegio es lo mismo que ud. ve en la casa.

0: Mi hija no lo puede hacer en este momento.

1: Creo que mi hija lo puede hacer o yo no lo he visto hacer esto en este momento.

2: Mi hija si puede hacer esto en este momento.

\section{SECCION 9}

71. - Puede su hija abrir la puerta dandole vuelta la manija?

72. - Si ud. le da 5 anillos y un estante para sostenerlos, puede su hija poner los 5 anillos en ella estante? (El orden en que lo hace no interesa)

73. - Si ud. le da una botella con M\&M's adentro, y le pone tapa puede su hija quitar la tapa para obtener los caramelos?

74. - Puede su hija separar 4 cuentas plasticas?

75. - Si ud. traza una linea de un lado al otro de la pagina, su hija intenta copiar lo que ud. hizo?

76. - Si ud. hace un tren con bloques ( 3 bloques juntos $y$ uno arriba de ellos), puede su hija hacer uno igual? 
Instrucciones: Por favor, conteste cada pregunta con su mejor abilidad. No haga el intento de hacerlo con su hija. Simplemente trate de recordar lo que ud. vió y dele el puntaje correspondiente de 0,1 y 2. Algunas preguntas van a ser muy fáciles y otras más dificiles de los que su hija puede hacer en este momento. Nosotros queremos ver si lo que vemos acá en el colegio es lo mismo que ud. ve en la casa.

0: Mi hija no lo puede hacer en este momento.

1: Creo que mi hija lo puede hacer o yo no lo he visto hacer esto en este momento.

2: Mi hija si puede hacer esto en este momento.

\section{SECCION 10}

77. - Puede su hija poner 9 ○ 10 bloques uno arriba del otro?

78. - Si ud. contruye un puente poniendo dos bloques cerca uno del otro y un tercer bloque arriba de los anteriores, puede su hija hacer uno como ella suyo?

79. - Si ud. le muestra a su hija una figura de un circulo, puede ella dibujar uno como ese con las dos puntas del circulo cerca?

80. - Puede ella lavarse las manos de manera tal que toda la palma como ella dorso de las manos le queden limpias?

81. - Puede su hija desabotonarse botones grandes?

82. - Puede ella cortar un pedazo en dos mitades despues que ud. le muestra como hacerlo? 
Instrucciones: Por favor, conteste cada pregunta con su mejor abilidad. No haga el intento de hacerlo con su hija. Simplemente trate de recordar lo que ud. vió y dele el puntaje correspondiente de 0,1 y 2 . Algunas preguntas van a ser muy fáciles y otras más dificiles de los que su hija puede hacer en este momento. Nosotros queremos ver si lo que vemos acá en el colegio es lo mismo que ud. ve en la casa.

0: Mi hija no lo puede hacer en este momento.

1: Creo que mi hija lo puede hacer o yo no lo he visto hacer esto en este momento.

2: Mi hija si puede hacer esto en este momento.

\section{SECCION 11}

83. - Usa su hija una mano mas que la otra?

84. - Puede ella quitarle la tapa a una botella en poco tiempo?

85. - Puede su hija ensaltar 5 o mas bolitas en un hilo?

86. - Cuando ud. le da cuerda a un juguete y se lo da a su hija, puede su hija darle cuerda al juguete cuando este termina de moverse?

87. - Puede su hija cortar una linea con las tijeras?

88. - Puede su hija dibujar dos lineas que se cruzan (en forma de cruzar) despues que ud. le muestra como hacerlo? 